\title{
GENDER UNEMPLOYMENT GAPS IN THE EU: BLAME THE FAMILY
}

\section{Alena Bičáková}
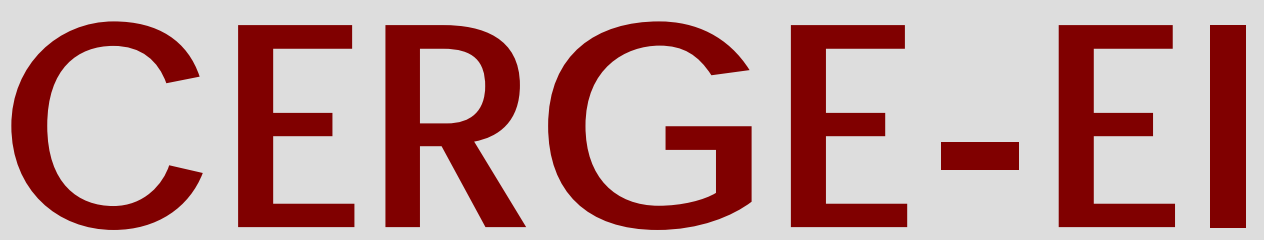

Charles University Centerfor Economic Research and Graduate Education Academy of Sciences of the Czech Republic Ec onomic s Institute 


\section{Working Paper Series 475 (ISSN 1211-3298)}

\section{Gender Unemployment Gaps in the EU: Blame the Family}

Alena Bičáková

CERGE-EI

Prague, December 2012 
ISBN 978-80-7343-279-9 (Univerzita Karlova. Centrum pro ekonomický výzkum a doktorské studium)

ISBN 978-80-7344-271-2 (Národohospodářský ústav AV ČR, v.v.i.) 


\title{
Gender Unemployment Gaps in the EU: Blame the Family*
}

\author{
Alena Bičáková \\ CERGE-EI ${ }^{\dagger}$ \\ December 2012 \\ Revised Version 2014
}

\begin{abstract}
We provide a parsimonious explanation for $80 \%$ of the extensive variation in gender unemployment gaps across the EU. We do so by dividing the EU countries into two groups and applying a single explanatory factor within each group. Specifically, we suggest that gender unemployment gaps arise through a mechanism that involves the effect of childbirth on women's labor force participation. We account for most of the cross-country differences in the said gaps by the prevalence of gender discrimination within the group of countries where many women permanently leave the labor force after childbirth and by the length of statutory family leaves within the remaining group of EU countries. In addition, gender unemployment gaps among individuals with children younger than five result, to a great extent, from the drop in female labor force participation after childbirth, which implies a negative selection of women into the labor force at that stage of life.
\end{abstract}

\begin{abstract}
Abstrakt
Tato studie nabízí úsporné vysvětlení rozdílů v genderové mezeře v nezaměstnanosti mezi zeměmi EU. Činíme tak rozdělením zemí EU do dvou skupin a v každé z nich používáme jediný vysvětlující faktor. Genderové mezery v nezaměstnanosti vznikají jako důsledek vlivu narození dítěte na participaci žen na trhu práce. Zatímco v zemích, kde ženy po narození dítěte odcházejí do domácnosti, lze vetšinu rozdílů v genderové mezeře $\mathrm{v}$ nezaměstnanosti vysvětlit mírou diskriminace žen, v ostatních zemích EU je tímto vysvětlujícím faktorem délka statutární rodičovské dovolené. Genderové mezery v nezaměstnanosti $\mathrm{v}$ populaci rodičů dětí mladších pěti let jsou do velké míry důsledkem poklesu participace žen na trhu práce po narození dítěte, což svědčí o negativní selekci žen na trh práce během tohoto životního období.
\end{abstract}

Keywords: Gender Unemployment Gap, Family Leave, Gender Discrimination JEL classification: J13, J71

*This project was financially supported by grant number P402/12/G130 from the Grant Agency of the Czech Republic. The author thanks Stěpán Jurajda, Randy Filer, and Michael Burda for valuable comments. All errors remaining in this text are the responsibility of the author.

${ }^{\dagger}$ CERGE-EI is a joint workplace of Charles University and the Economics Institute of the Academy of Sciences of the Czech Republic, Politickych veznu 7, 11121 Prague, Czech Republic. E-mail: alena.bicakova@cerge-ei.cz 


\section{Introduction}

The rise in educational attainment and labor force participation of women has contributed to the convergence in gender gaps in various labor market outcomes over the last decades. Yet, gender differences in the labor market still persist, and their size varies considerably across countries (OECD 2002; OECD 2008). Research looking for an explanation of these cross-country differences has predominantly focused on gender wage gaps: see Altonji and Blank (1999) for a review, and subsequent studies such as Blau and Kahn (2003), Weichselbaumer and WinterEbmer (2005) or Weichselbaumer and Winter-Ebmer (2007). There are papers that discuss gender employment gaps (Algan and Cahuc 2005; Bertola, Blau, and Kahn 2007); ${ }^{1}$ however, only one study, Azmat, Güell, and Manning (2006) - hereinafter AGM, has tried to account for the cross-country variation in gender differences in unemployment.

The aim of the present paper is to explain the cross-country variation in gender unemployment gaps in the European Union. While our findings are in line with the general conclusions of AGM that human capital, family and labor market institutions, as well as prejudice are important to explain the gender differences in unemployment across countries, this paper offers both a more parsimonious and a more specific account of the substantial cross-country variation in gender unemployment gaps in twenty-one countries of the European Union a decade later. ${ }^{2}$ We show that $80 \%$ of this variation can be explained by dividing EU countries based on female labor force participation behavior after childbirth into two groups and applying a single explanatory factor within each: the statutory duration of paid family leave in one, and the prevalence of gender discrimination in the other.

Gender unemployment gaps are at least as important as the gaps in other labor market outcomes. Unemployment - while not necessarily affecting the majority of

\footnotetext{
${ }^{1}$ While the latter paper also considers gender-specific unemployment outcomes, its focus is limited to the effect of labor market institutions, in particular, collective bargaining.

${ }^{2}$ AGM focus on only West-European countries and the US in the 1990s. Section A.3 in the Appendix compares the data, the methods, and the main results of their study to ours.
} 
the population in the same way gender wage gaps do - has more serious consequences for one's well-being than the wage level, and these are likely to be more serious for women than men. Unemployment spells are not just periods of forgone earnings but, primarily, of human capital stagnation or loss. They may stigmatize a worker's career path or have severe negative psychological effects (Clark and Oswald 1994). Job displacement lowers future earnings (Jacobson, LaLonde, and Sullivan 1993) and the effect may persist even in the long run (Eliason and Storrie 2006). Long periods of unemployment can discourage the unemployed from staying in the labor force. ${ }^{3}$ This so-called discouraged worker effect occurs primarily among secondary earners, a household role typically assumed by women. Moreover, job loss has been shown to have a negative impact on fertility decisions (see, for example, Adsera 2005) revealing a link between gender unemployment gaps and demographic trends. Gender unemployment gaps also affect the magnitude of gender wage gaps, both causally, via the effect of unemployment spells on future earnings, and mechanically, via the selection effect. ${ }^{4}$

While much of the impact surveyed above pertains to spells of inactivity as well as those of unemployment, the earlier is typically regarded as "voluntary", as inactive individuals - in contrast with the unemployed - do not search for a job. ${ }^{5}$ Past research has shown that the borderline between unemployment and inactivity is not clear-cut (Jones and Riddell 1999; Brandolini, Cipollone, and Viviano 2006), suggesting that gender differences in employment rates may be a better measure of the position of women in the labor market rather than gender unemployment gaps. We show, however, that considering the two non-employment states (unemployment and inactivity) separately and understanding how they affect

\footnotetext{
${ }^{3}$ For example Blundell, Ham, and Meghir (1998) and Benati (2001) show the empirical importance of this phenomenon.

${ }^{4}$ When hypothetical wages of the unemployed are lower than wages of those who work, higher gender unemployment gaps result in lower wage gaps. Olivetti and Petrongolo (2008) show that gender differences in wages in countries with large gender employment gaps considerably underestimate the gender wage gaps that would be observed if female and male employment rates were the same.

${ }^{5}$ The International Labor Organization defines unemployment as follows: an unemployed is an individual who does not have a job, has been actively looking for a job in the past four weeks, and is available to start working within two weeks.
} 
each other over individuals' life-cycle is a necessary first step for an analysis of the cross-country variation in gender employment gaps.

How large are gender unemployment gaps? While no major gender differences in unemployment rates have been observed in Anglo-Saxon countries since the 1990s ${ }^{6}$ gender differences between female and male unemployment rates exceed two percentage points (p.p.) in more than one-third of the countries of the European Union, and many of them do not show any sign of convergence. In 2007, gender unemployment gaps across the EU ranged from a small negative gender unemployment gap (i.e. in favor of women) in Ireland and no gaps in the three Baltic States, Finland, Germany, Hungary, Luxembourg, and the UK, to gender unemployment gaps exceeding 3 p.p. in Greece, Italy, Portugal, Spain, the Czech Republic, and Slovakia. When we smooth out the business cycle effects and look at the average gender unemployment gaps over 2003-2007, as plotted in Figure 1, the cross-country variation and countries' ranking remain almost the same, with the average gender unemployment gaps ranging from about -1 p.p. to 8 p.p. ${ }^{7}$

The aim of this paper is to explain the cross-country variation in gender unemployment gaps, as documented in Figure 1, using 21 national labor force surveys standardized into the European Union Labor Force Survey dataset. ${ }^{8}$ Our definitions and the sample choice are in line with the previous literature: We use the International Labor Organization (ILO) definition of unemployment and define gender unemployment gap as the difference between female and male ILO unemployment rates. In order to ensure a comparable size of potential labor force across countries, we avoid cross-country differences at the beginning and end of a labor market career (which might be due to different educational systems and retirement schemes) by limiting our analysis to prime age individuals, i.e. those between 25 and 54 years

\footnotetext{
${ }^{6} \mathrm{AGM}$ conjecture that this may be one of the reasons for the lack of research interest in gender unemployment gaps as the majority of the international research had been carried out on data from Anglo-Saxon countries.

${ }^{7}$ While gender unemployment gaps have decreased in some of the Benelux and Mediterranean countries, their ranking in the EU have remained stable over the last ten years. See Figure A.3 in the Appendix.

${ }^{8}$ The exact source of the data, the definition of the sample, and the data description is in Section A.1.1 in the Appendix.
} 
Figure 1: Gender Unemployment Gaps in 2003-2007 (5-Year Average)

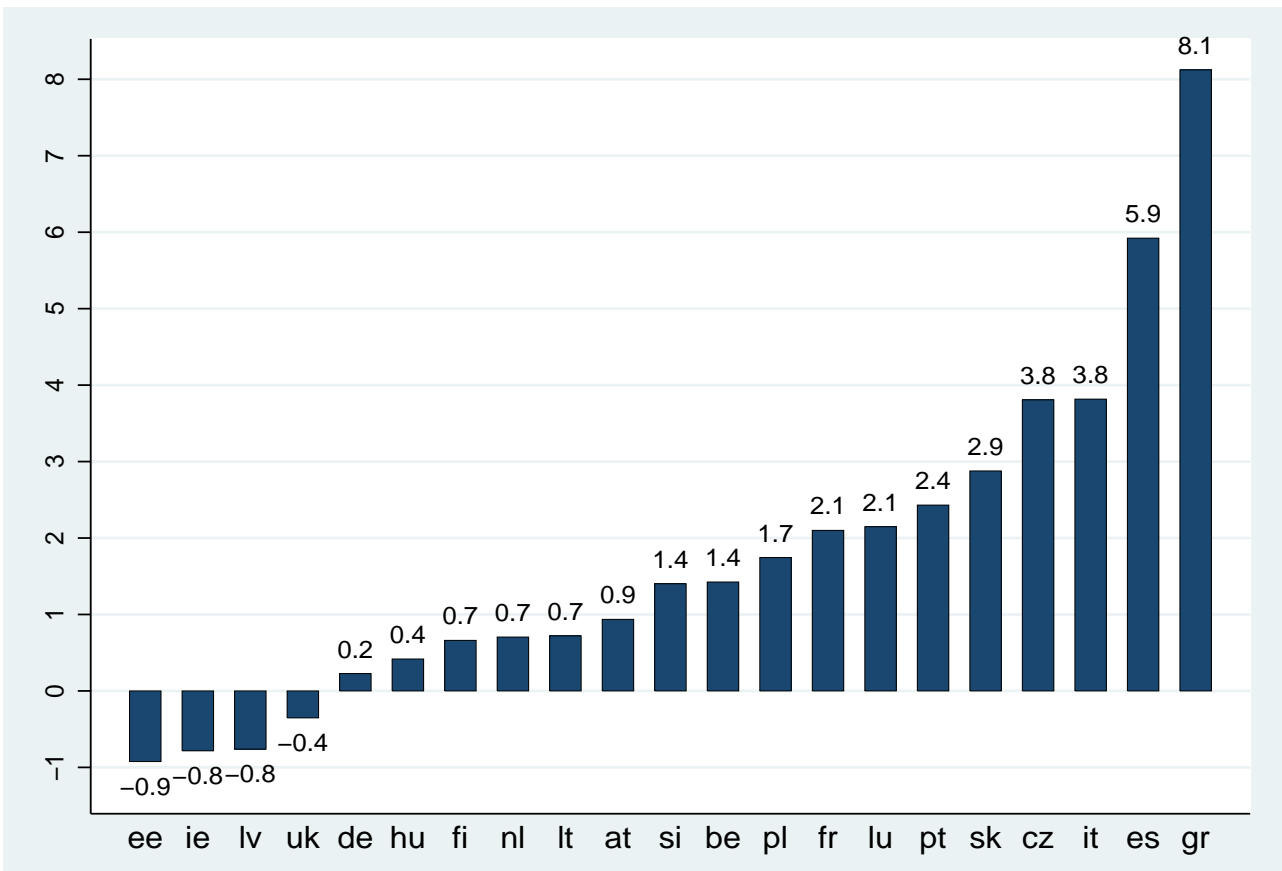

Note: EU LFS data, sample of prime age individuals (25-54 years old). Standard ILO definition of unemployment. Own calculations. Weighted by sampling weights. Gender unemployment gaps are measured in percentage points as the differences between female and male unemployment rates. Unemployment rate is defined as the share of unemployed in the labor force. Individuals on family leave are universally coded as out of the labor force. The coefficient of variation is 1.3.

of age. ${ }^{9}$

We next provide a roadmap to our paper by outlining the steps of our analysis and the key findings. Using a flexible version of the Oaxaca-Blinder decomposition we find, first, that gender differences in observed pre-market human capital $^{10}$ (acquired before individuals enter the labor market) explain only $23 \%$ of the cross-country variation in gender unemployment gaps. As gender differences in pre-market human capital are rather small, the pre-market human capital adjusted gender unemployment gaps - i.e., the hypothetical gender unemployment gaps under pre-market human capital equality between women and men - do not substantially differ from the unadjusted gaps, and the adjustment reduces the coefficient of variation of gender unemployment gaps across countries by only about one fourth (from 1.3 to 1$)$.

\footnotetext{
${ }^{9}$ The correlation between gender unemployment gaps (averaged over 2003-2007) among prime age individuals and among all individuals in the population in the 21 countries is 0.98 , suggesting that our main conclusions should be robust to the choice of the sample.

${ }^{10}$ We adopt this term from Altonji and Blank (1999).
} 
We next focus on market human capital (acquired after individuals enter the labor market) and explore the role of children as the main factor affecting gender differences in work experience and human capital accumulation since the beginning of the career. Presence of children turns out to be crucial for the existence of gender differences in unemployment: gender unemployment gaps do not exceed 1 p.p. among individuals without children younger than 15 in the family in any of the countries except in Greece, Italy, and Spain; among individuals with children, on the other hand, gender unemployment gaps exceed 2.5 p.p. in 16 out of the 21 countries.

We then disaggregate the data by the following five stages of family life defined by age, fertility, and the age of children: individuals younger than 40 without children younger than 15, with children between 0 and 4 , with children between 5 and 9, with children between 10 and 14, and individuals over 40 without children younger than 15. Gender unemployment gaps are universally the greatest at the second stage of family life, the one immediately following the last childbirth, due to the high unemployment rate among mothers of children between 0 and 4 . The high female unemployment rate at that stage turns out to be a direct consequence of the reduction in the denominator in the unemployment rate formula driven by the labor force withdrawal of women who take family leaves after childbirth. It is only at the third stage of family life (with children between 5 and 9 years of age) that gender unemployment gaps, which are still substantial in size in a majority of the countries, reflect the true rise in female joblessness relative to that of men.

Given the close relationship between female labor force participation and gender unemployment gaps, we next construct the labor force participation profiles of women and men over the five stages of family life as defined above. We find that: (1) In most of the EU countries, gender labor force participation gaps open up only after women have children. (2) EU countries divide into what we call the temporary leave countries, where women take family leaves of various lengths after childbirth and then typically return again to the labor force, and the permanent 
withdrawal countries, where the shape of the participation profiles suggests that the majority of women who leave the labor force after childbirth never return. ${ }^{11}$ The eight permanent withdrawal countries include Ireland, the Benelux and the Mediterranean countries except for France; the remaining thirteen countries are the temporary leave countries. (3) In the temporary leave countries, there are gender unemployment gaps only among individuals with children younger than 15 whereas among childless individuals and individuals with children 15 or older, the maximum gap is only about 1 p.p. In the four Mediterranean permanent withdrawal countries, on the other hand, there are gender unemployment gaps in favor of men also among individuals without children younger than 15 in the family.

Finally, it turns out that the observed behavioral patterns driving the crosscountry variation in gender unemployment gaps can be explained to a great degree by a single institutional factor, a different one for the two types of countries: by the statutory duration of paid family leave in the temporary leave countries and by the Eurobarometer measure of perceived prevalence of gender discrimination in the permanent withdrawal countries. When we adjust gender unemployment gaps for gender differences in pre-market human capital, focus separately on individuals with children below 15 and those without, and combine all the steps of our proposed explanation into a single regression, we can explain $80 \%$ of the cross-country variation in gender unemployment gaps by simply applying two explanatory factors, one for the temporary leave countries and one for the permanent withdrawal countries.

The paper is organized as follows: In the next section, we ask to what extent gender differences in human capital explain the observed gender unemployment gaps. The third section explores gender differences in unemployment and labor force participation behavior across the five stages of family life. In the fourth section, we focus on the relationship between female labor force participation and gender unemployment gaps. The fifth section consists of two parts: The first part

\footnotetext{
${ }^{11}$ As the data only permit us to construct participation profiles from cross-sectional data, the observed permanent withdrawal could be also driven by inter-cohort changes, namely, by the increase in female labor force participation. A simple version of a cohort analysis in Appendix A.2 shows that while the profiles shift upward over time, their shape remains the same across cohorts.
} 
presents our explanation of the cross-country variation in gender unemployment gaps using the two explanatory factors, the statutory duration of paid family leave and the prevalence of gender discrimination, within a simple regression framework. The second part is devoted to the evidence of the behavioral impact of these two factors. Sixth section concludes.

\section{Gender Differences in Human Capital}

It is a well-established fact that there is a negative relationship between the level of human capital and the risk of being unemployed (Mincer 1993). Unemployment rates concentrate among the least-educated individuals and substantially decrease with every education level almost universally across the OECD countries (OECD 2008). In this section, we ask whether the observed gender unemployment gaps and their cross-country variation can be explained by gender differences in human capital. We separately focus on the level of human capital with which individuals enter the labor market (pre-market human capital) and on the human capital accumulated while in the labor market (market human capital).

\subsection{Pre-Market Human Capital}

We measure pre-market human capital by the level of education within a given age cohort. ${ }^{12}$ This allows us to compare women and men who entered the labor market with the same level of human capital at the same time and have had the same number of years available to accumulate market human capital until today. ${ }^{13}$ In order to determine how much of the observed gender unemployment gaps can

\footnotetext{
${ }^{12}$ Admittedly, education, even if widely used by previous research and highly correlated with the risk of unemployment (Mincer 1993), is a rather crude measure of pre-market human capital. We discuss the possibility that (some of) the variation in gender unemployment gaps is driven by gender differences in pre-market human capital investments that are unobserved in the data we have, later in the text whenever relevant.

${ }^{13}$ In other words, when comparing individuals, we condition on what is known as the potential work experience. This approach also allows us to control for potential cohort differences in the quality of education, which is likely to be important, in particular in the New-EU member states, where the analyzed workforce still contains those educated under the Communist regime and those educated after the transition to the market economy.
} 
be explained by gender differences in pre-market human capital, we use a flexible version of the Oaxaca-Blinder decomposition based on a simplified version of the methodology from Nopo (2008), where the simplification results from the fact that we condition only on discrete explanatory variables.

Consider $J$ cells based on discrete versions of individual characteristics $X$ (in our case, these are 18 cells constructed on the basis of three levels of education and six age categories). ${ }^{14}$ The overall gender unemployment gap $U_{g a p}$ defined as the difference between the female $u^{F}$ and male $u^{M}$ unemployment rate can be expressed in terms of the $J$ groups as follows:

$$
U_{\text {gap }}=u^{F}-u^{M}=\sum_{j} w_{j}^{F} u_{j}^{F}-\sum_{j} w_{j}^{M} u_{j}^{M}
$$

where $u_{j}^{G}$ is the unemployment rate in cell $j$ for gender $G$, and $w_{j}^{G}$ is the share of individuals of gender $G$ from cell $j$ in the labor force of gender $G$. Adding and subtracting terms for the overall gender-neutral unemployment rates weighted by the gender specific weights, $\sum_{j} w_{j}^{F} u_{j}$ and $\sum_{j} w_{j}^{M} u_{j}$, we get

$$
U_{\text {gap }}=\underbrace{\sum_{j} w_{j}^{F}\left(u_{j}^{F}-u_{j}\right)}_{A}+\underbrace{\sum_{j} w_{j}^{M}\left(u_{j}-u_{j}^{M}\right)}_{B}+\underbrace{\sum_{j}\left(w_{j}^{F}-w_{j}^{M}\right) u_{j}}_{C} .
$$

While $A$ and $B$ reflect the part of the unemployment gap that is due to gender differences in unemployment within the respective cells, $C$ captures the gender differences in the distribution of individuals across the cells. In terms of the traditional terminology of gender gap decompositions, $C$ is the part of the gender unemployment gap that is driven by differences in observed characteristics, and $A+B$ is the part of the gap that remains unexplained. Note that $A+B$ measures the counterfactual - the hypothetical gender difference in unemployment under pre-market human capital equality. We present these "pre-market human capital adjusted" gender unemployment gaps in Figure 2, next to the unadjusted ones, with

\footnotetext{
${ }^{14}$ This is the most detailed categorization we can achieve given the information available in the data and given the need to ensure that each cell is sufficiently populated.
} 
countries ordered by the unadjusted gaps as in Figure 1. Both gender unemployment gap measures are constructed annually but are then averaged over the studied period 2003-2007 in order to smooth out any cyclical factors at the aggregate level.

Figure 2 suggests that in a majority of the countries, the gender unemployment gap under pre-market human capital equality exceeds the observed gender unemployment gap, which implies that women have a more favorable distribution of premarket human capital than men. This is not surprising, given the well documented universal rise in female education over the last decades, and the fact that women are on average more educated than men in many developed countries (OECD 2002). The counterfactual gap is lower than the unadjusted gap in only five countries, Figure 2: Raw and Pre-Market HC Adjusted Gender Unemployment Gaps

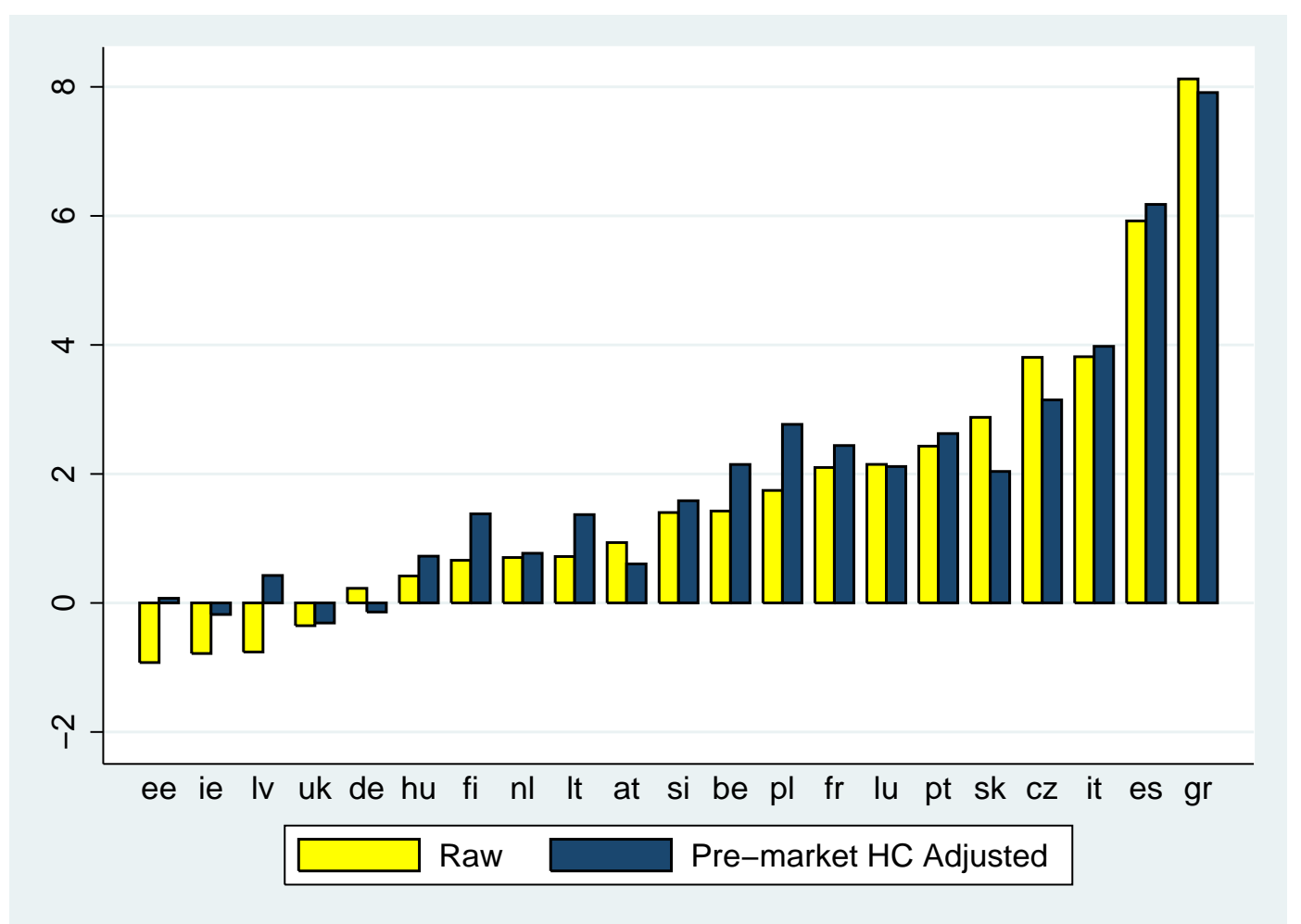

Note: Raw gaps are five-year averages of gender unemployment gaps among prime age individuals over 2003-2007, constructed using sampling weights. The corresponding hypothetical gender unemployment gaps under pre-market human capital equality are constructed based on a flexible version of Oaxaca-Blinder decomposition using age and education groups as individual characteristics. The pre-market human capital adjusted unemployment gaps are five-year averages of the constructed hypothetical gaps, using sampling weights, over 2003-2007. Countries are ordered by the raw (unadjusted) gaps. Gaps are in p.p.

revealing that part of the observed gender unemployment gap (35\% in Austria, 29 $\%$ in Slovakia, $17 \%$ in the Czech Republic, $3 \%$ in Greece and 1.5 \% in Luxembourg) 
is due to better pre-market human capital characteristics of men when compared to women. ${ }^{15}$ We conclude that not only do the gender differences in pre-market human capital explain very little of the observed gender unemployment gaps and their cross-country variation (the coefficient of variation of the pre-market human capital adjusted gender unemployment gaps is 1, compared to the corresponding measure of 1.3 for the unadjusted gaps), but they reveal that in a majority of the countries, the observed gender unemployment gaps actually underestimate the true gender differences in unemployment.

\subsection{Market Human Capital and the Role of Children}

Gender differences in market human capital accumulation can arise for various reasons, yet there is one unavoidable factor which makes women's and men's career paths always unequal: childbirth. Following previous research which has faced similar data limitations, we use the presence of children as a proxy for gender differences in market human capital accumulation. ${ }^{16}$ Figure 3 reveals that the effect of children on gender differences in unemployment is indeed enormous. The two panels of Figure 3 plot male unemployment rates against female unemployment rates in the 21 countries separately for individuals with and without children younger than 15 present in the household.

In the left panel, a vast majority of the points are around or to the left of the 45 degree line, suggesting that in most of the countries there are no gender unemployment gaps in favor of men among individuals without children. The only exceptions are Greece, Italy and Spain, where the female unemployment rate substantially exceeds that of the male even among the individuals without children. The right panel, where all data points are to the right of the 45 degree line, reveals

\footnotetext{
${ }^{15}$ The observed gender unemployment gap in favor of men in Germany turns into a gap in favor of women under pre-market human capital equality, although the absolute values of the gender differences are not statistically significantly different from zero.

${ }^{16}$ Ideally, market human capital should be measured both by the intensity of human capital accumulation at work (via job training or other on-the-job professional development) as well as its duration (as given by the number of years of work experience and job tenure). None of this information is available in our data, and if available for the employed, it is missing for the unemployed and the ones who are out of the labor force.
} 
Figure 3: Gender Differences in Unemployment by the Presence of Children

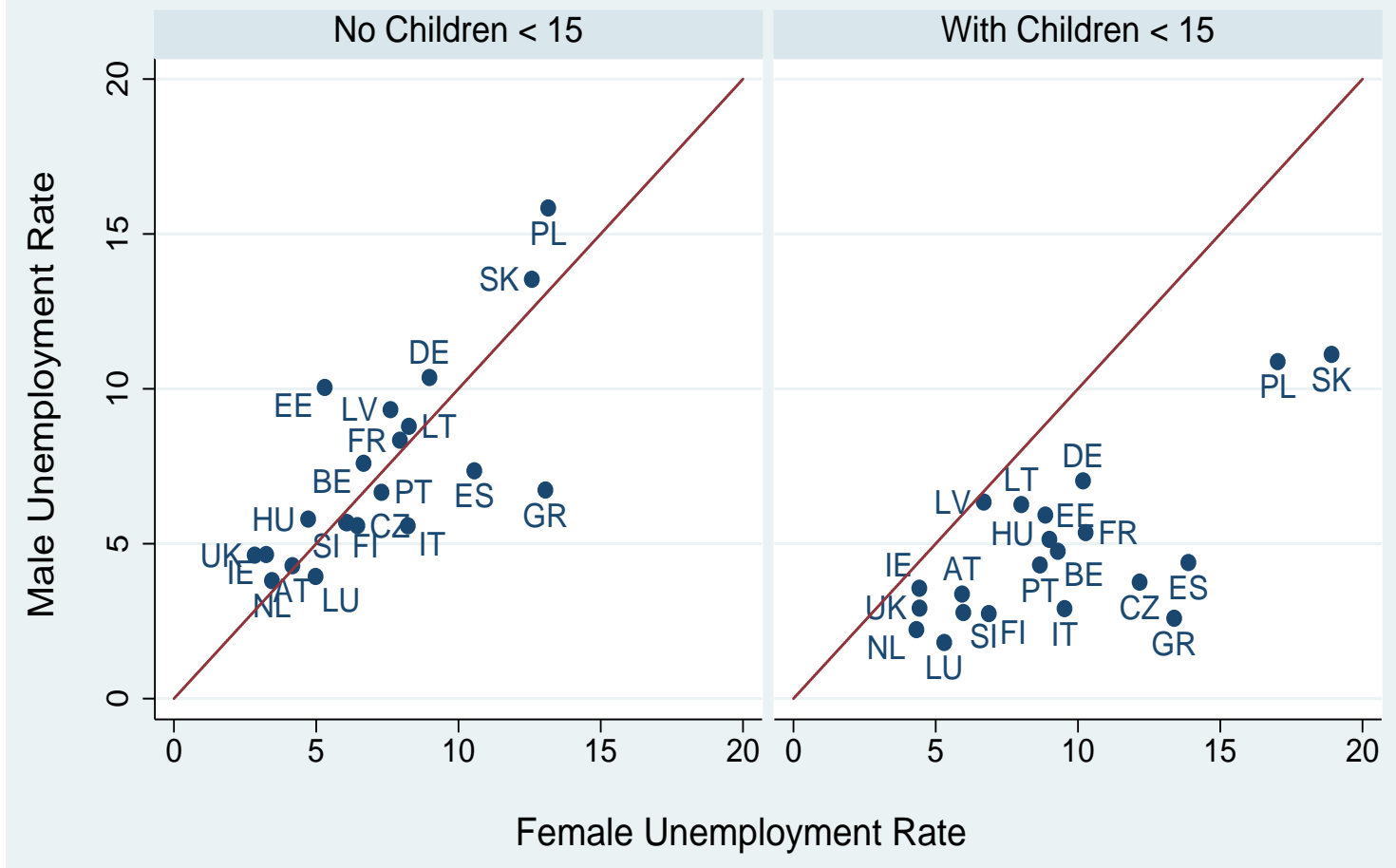

Note: Unemployment rates (in \%) are the five-year averages over 2003-2007 constructed for the two groups of prime age individuals respectively: with children younger than 15 present in the household (left panel) and without (right panel). Figures contain the 45 degree line, which correspond to no gender differences in unemployment. Sampling weights are used for the construction of the annual unemployment rates.

non-negligible gender unemployment gaps in favor of men among individuals with children in almost all the countries studied. Finally, comparing the two panels, we see that moving from left to right, the country-specific data points move East more than South, indicating that gender unemployment gaps among individuals with children are driven more by the above-average female unemployment rates than the below-average male unemployment rates when compared to individuals without children. ${ }^{17}$

Three conclusions can be derived from Figure 3: First, any analysis of gender unemployment gaps should primarily concentrate on the presence of children as the main factor which makes female and male unemployment rates diverge. Second, gender unemployment gaps should be discussed separately for individuals with children and without children present in the household. Third, the focus of the research

\footnotetext{
${ }^{17}$ Childless individuals include both childless individuals and individuals whose children are grown.
} 
should be on the above-average unemployment rates of women with children relative to men and women without children as that seems to be the main source of the observed gender differences in unemployment.

\section{Gender Gaps across Five Stages of Family Life}

We have so far interpreted the presence of children as an indicator of women's past career interruptions that lead to gender differences in market human capital. The presence of young children may also increase their mothers' risk of unemployment by reducing their work effort when they are working or their job search effort when they are unemployed (Becker 1985). In order to understand better how children of various ages affect gender differences in unemployment, we next disaggregate our sample of prime age individuals by the individual's age, fertility, and the age of children. In particular, we divide individuals in our sample into the following five stages of family life: individuals younger than 40 with no children below 15 (Group 0 ); individuals with the youngest child younger than 5 (Group 1); with the youngest child younger than 10 but at least 5 years old (Group 2); with the youngest child younger than 15 but at least 10 years old (Group 3); and individuals older than 40 with no children younger than 15 present in the family (Group 4). Individuals who have children at some point in their life go through all five stages of family life; individuals who have no children move directly from Group 0 to Group 4. While Groups 1-3 represent individuals with children at three different stages since the last childbirth, Group 0 captures childless individuals who may or may not have children in the future, and Group 4 comprises a mixture of individuals above 40 who have never had children or whose children are older than $15 .^{18}$

As we neither have panel data with individual histories, nor we can construct a pseudo-panel based on cohorts because the time span of the data is too short

\footnotetext{
${ }^{18}$ We cannot distinguish between individuals who never had children and those whose children have already grown up. There are certainly both ex ante (Group 0) and ex post (Group 4) differences between career paths of individuals who plan to have children and those who do not, which we are forced to ignore and to interpret the results for the two endpoints of family life as averaged over the two types of individuals. We discuss this shortcoming whenever relevant.
} 
and age information is only available in five-year age bands, we construct the five stages of family life from cross-sectional surveys based on age, fertility, and the age of the youngest child. The shape of the presented profiles may therefore reflect the within-cohort evolution as well as changes between cohorts. Note, however, that the fact that the three inner parts of the profiles are constructed based on the age of the youngest child rather than the age of the mother brings additional variation into the within-cohort and across-cohort divides. We believe that profiles based on an individual's age and the age of the youngest child may be preferable to cohort-based profiles for our present question, as aggregate economic conditions are more likely to affect the shape (and not the level) of the latter than of the former. Moreover, all outcomes, constructed from the annual cross-sectional surveys, are measured as five-year averages over 2003-2007 to smooth out business-cycle effects.

\subsection{Unemployment Profiles: Gaps, Rates, and Shares}

Figure 4 shows the evolution of gender unemployment gaps across the five stages of family life as defined above. The typical gender unemployment gap profile is hump-shaped, suggesting that gender unemployment gaps are concentrated almost solely during the first ten years from the last child's birth. In over two-thirds of the countries, gender differences in the unemployment rate reach their maximum during the first stage following childbirth (Group 1), and then gradually decrease as children get older (Groups 2 and 3). In 15 of the 21 countries, gender differences in unemployment rates are either smaller than 1 p.p. or in favor of women among the childless and those with children 15 or older (Groups 0 and 4 ). ${ }^{19}$ Finally, it is only in Greece, Italy, Spain, Slovenia, and Finland that women have a substantially higher risk of being unemployed already when they are young and before they start

\footnotetext{
${ }^{19}$ The almost zero gender differences in unemployment in these two groups may underestimate the gender unemployment gaps among the individuals who plan to have children and among those whose children are grown up, as they are combined with individuals who do not plan to have children (Group 0) and with individuals who never had children (Group 4), respectively. This would, however, require substantial gender unemployment gaps in favor of women among truly childless individuals (who form less than one-third of the sample, according to demographic trends), which is unlikely.
} 
having children (Group 0).

Figure 5 confirms that it is the evolution of the female unemployment rate rather than the male unemployment rate that contributes most to the documented gender unemployment gap profiles over the five stages of family life. Similar to gender unemployment gaps, female unemployment rates are also hump-shaped across the family life with the highest values at the two stages following childbirth. ${ }^{20}$ Male unemployment rate profiles, on the other hand, are almost always much flatter than those of women. While we can detect - in particular among some of the Mediterranean countries and in Poland - a mirror image of the hump shape in the unemployment rates of women in the shape of male unemployment rate profiles, suggesting that men with children in the household have lower unemployment rates than men without, it is much less pronounced. ${ }^{21}$ While this so-called "family gap" in the male unemployment rate somewhat contributes to the observed gender unemployment gaps, its impact is almost always of a second-order importance relative to the corresponding "family gap" in female unemployment rates.

To disentangle the changes in unemployment rates due to changes in the number of unemployed from those due to changes in the size of the labor force, ${ }^{22}$ Figure 5 also shows the evolution of the gender-specific shares of the unemployed in the respective population sub-groups. We see that while the male unemployment rate and the share of the unemployed among men are almost indistinguishable across the five stages of family life, the female unemployment rate and the share of the unemployed among women often diverge. Prior to discussing the differences between the two alternative measures of unemployment, we first complete the picture by exploring the gender-specific labor force participation behavior across the five stages

\footnotetext{
${ }^{20}$ Some countries such as Greece or Italy, however, struggle with high unemployment rates among the young (Group 0), irrespective of gender, which somewhat alters the typical shape of the female and male unemployment profiles.

${ }^{21}$ The fact that men with families have better labor market outcomes than the ones without is well-established. Previous research has focused primarily on the question whether this so-called "family gap" is driven by a selection of above-average-productivity men to marry or by the fact that family increases men's effort at work and reduces their reservation wage (see for example Korenman and Neumark 1991; Ginther and Zavodny 2001).

${ }^{22}$ Unemployment rate is defined as the ratio of the number of the unemployed divided by the number of individuals in the labor force.
} 
of family life.

Figure 4: Gender Unemployment Gaps by Fertility, Age, and Age of Children

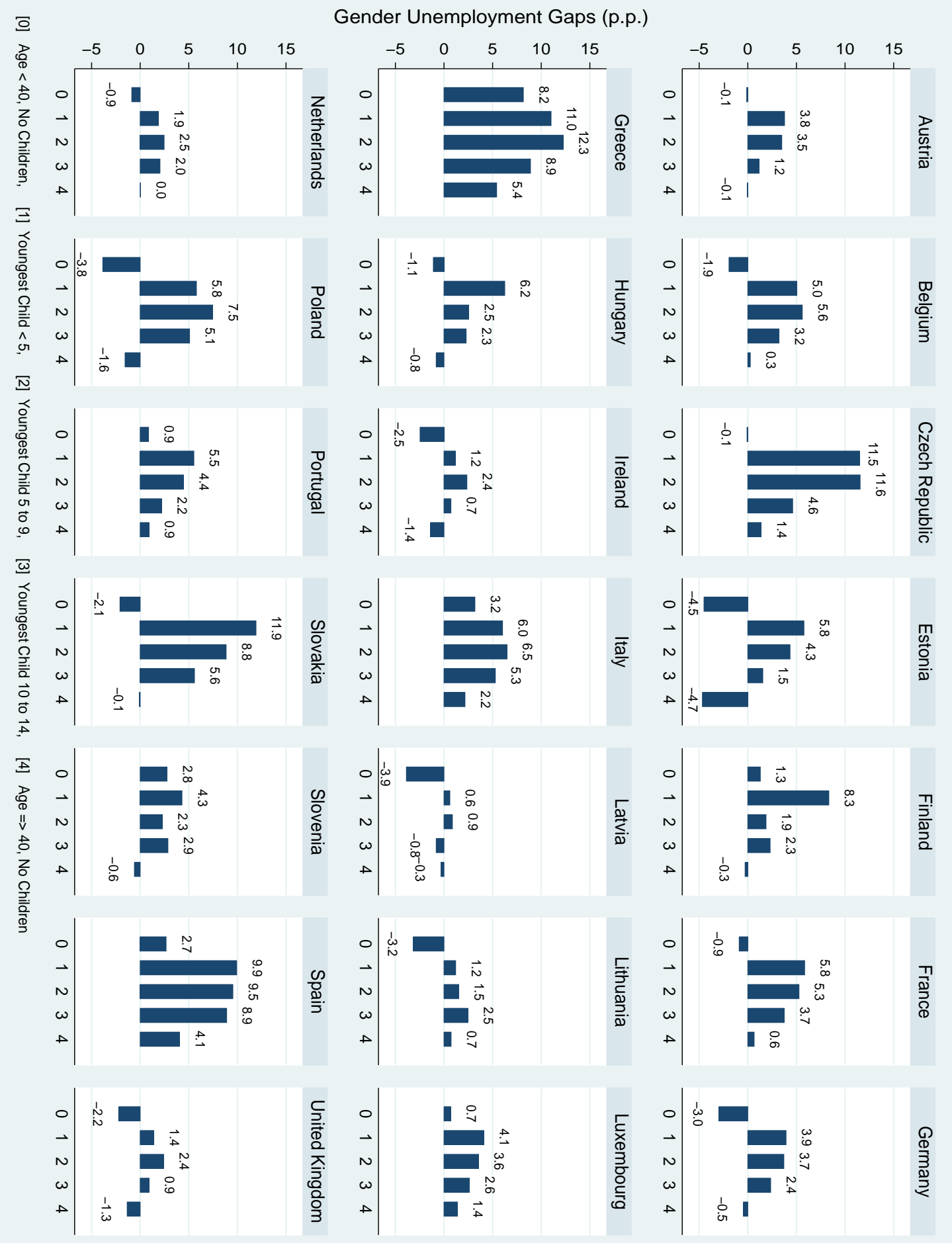

Note: The gender unemployment gaps among prime age individuals (5-year averages across 2003-2007, constructed using sampling weights) by the five stages of family life defined as follows: individuals younger than 40 with no children younger than 15 in the family (Group 0); individuals with at least one child below 5 (Group 1); individuals with the youngest child between 5 and 9 (Group 2); individuals with the youngest child between 10 and 14 (Group 3); and individuals aged 40 or more with no children younger than 15 present in the family. 
Figure 5: Unemployment Rates and Shares of the Unemployed across Family Life

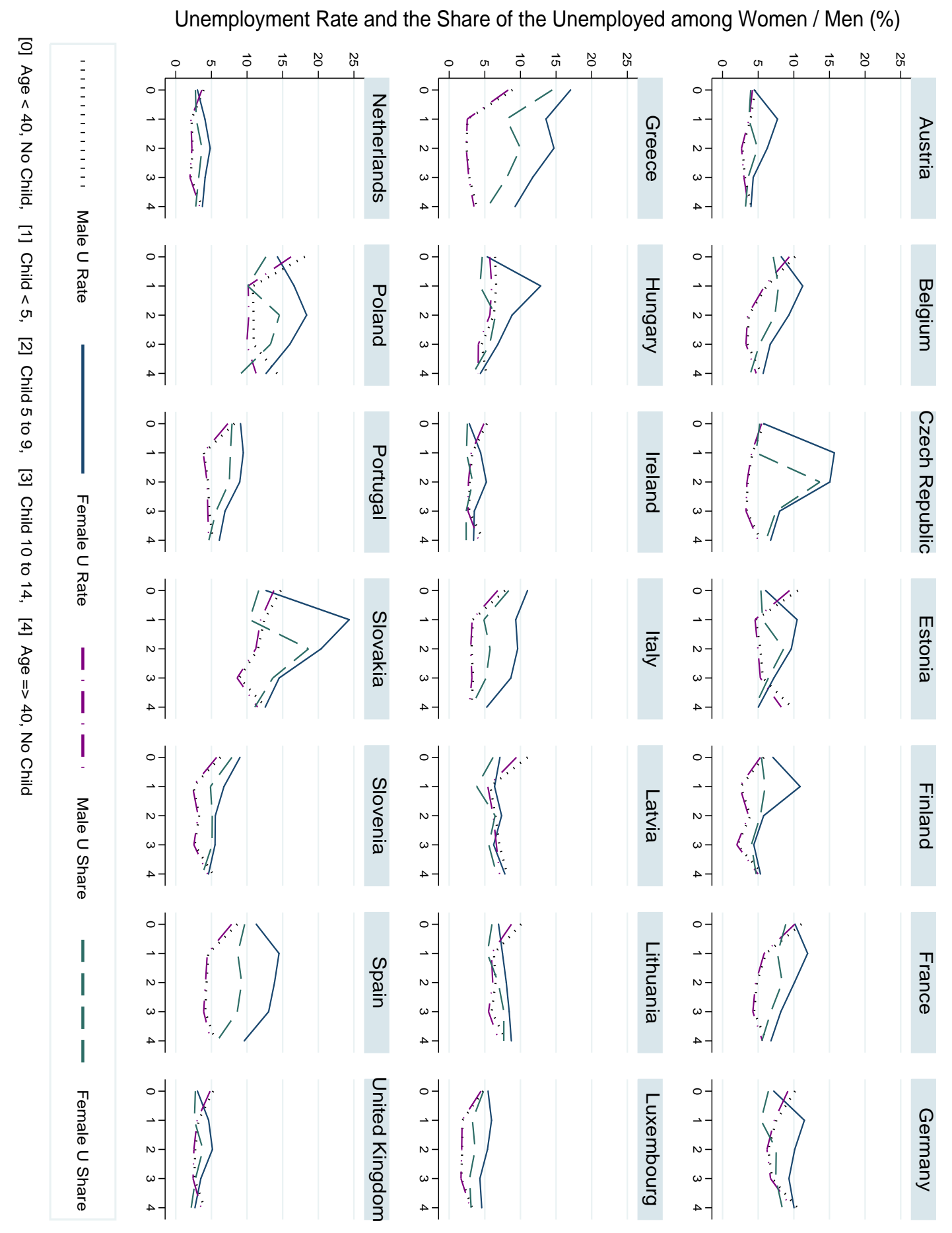

Note: U-Rate is the unemployment rate, U-share is the share of unemployed in the population of the respective sub-group of prime age individuals. Both measures are expressed in percentages and represent 5-year averages over 2003-2007 (underlying annual figures are constructed using sampling weights). The five stages of family life are defined as follows: individuals younger than 40 with no children younger than 15 in the family (Group 0); individuals with at least one child below 5 (Group 1); individuals with the youngest child between 5 and 9 (Group 2); individuals with the youngest child between 10 and 14 (Group 3); and individuals aged 40 or more with no children younger than 15 present in the family. 


\subsection{Labor Force Participation Profiles}

Figure 6 suggests that the labor force participation behavior of men does not differ substantially across countries: the male participation rate remains stable across the five stages of family life and is always above that of women. ${ }^{23}$ On the other hand, the female labor force participation varies substantially both across different stages of family life as well as across countries. Based on the shape of the labor force participation profiles of women, we can identify two types of countries: which we shall call the temporary leave countries and the permanent withdrawal countries.

In the temporary leave countries, presented in the top half of Figure 6, female participation rates are (with the exception of Finland) the same as those of men at the first stage of family life, before the potential family formation (Group 0). It is only at the second stage (Group 1) that gender labor force participation gaps open up, as women leave the labor force due to childbirth. After the family-related career interruption, women start returning to the labor force again as children get older (Group 2 or 3). At the last stage of family life (Group 4), the female labor force participation rate converges back to the male participation rate, and the gender participation gap either disappears or substantially narrows relative to the stages directly following childbirth. In the permanent withdrawal countries, presented in the bottom half of Figure 6, gender participation gaps, which are in some of the countries present already before the family formation (Group 0), also widen at the second stage as women leave the labor force after childbirth (Group 1), but, in contrast to the temporary leave countries, they persist over the rest of family life. There are 13 temporary leave countries and 8 permanent withdrawal countries. The latter include Ireland, the Benelux countries, and the Mediterranean countries except for France.

\footnotetext{
${ }^{23}$ Consistent with the "family gap" phenomenon mentioned earlier, male labor force participation is always the highest in families with young children; however, the differences are small.
} 
Figure 6: Labor Force Participation Profiles over Five Stages of Family Life

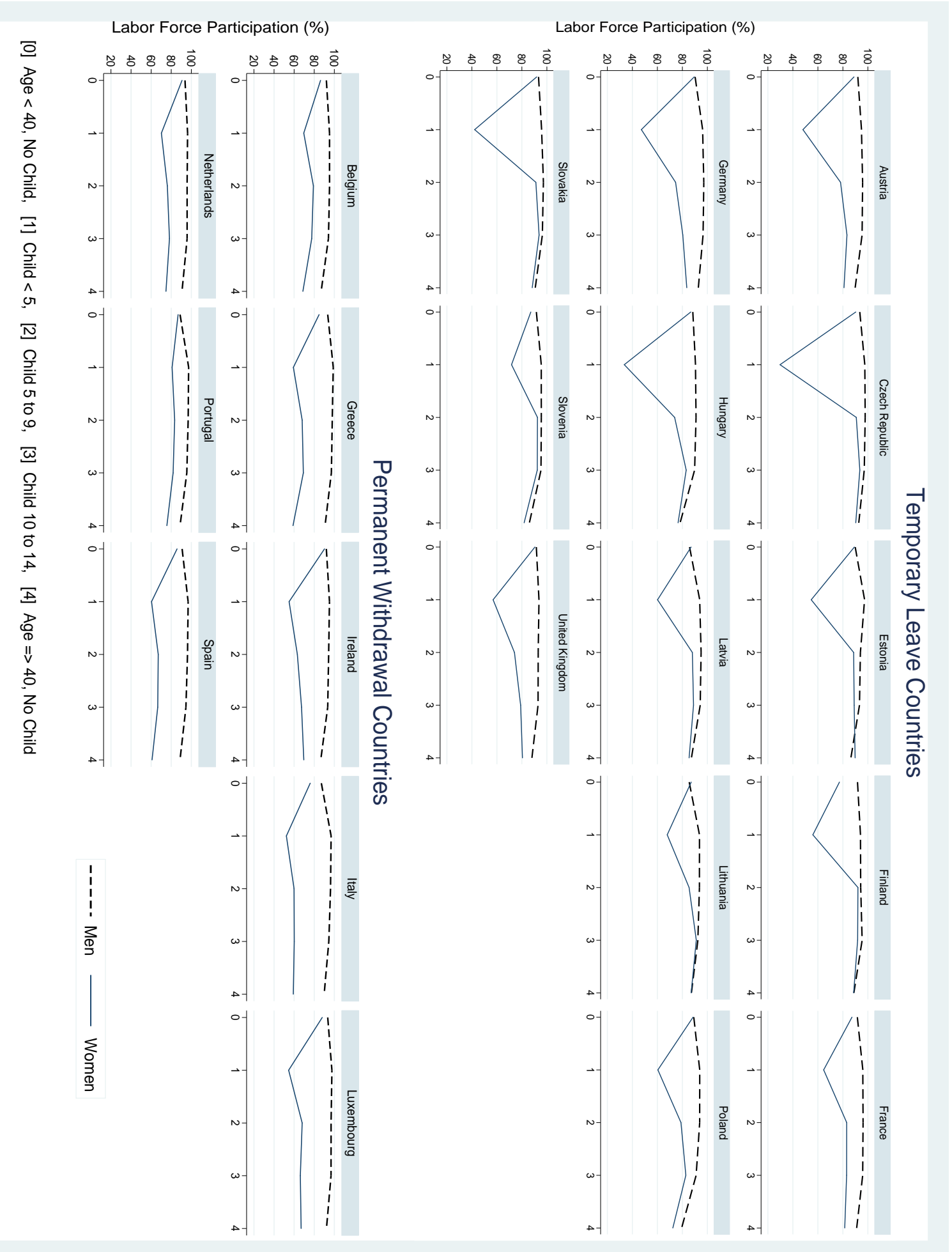

Note: Gender and group specific labor force participation rates among prime age individuals are expressed in percentages and represent 5-year averages over 2003-2007 (underlying annual figures are constructed using sampling weights). The five stages of family life are defined as follows: individuals younger than 40 with no children younger than 15 in the family (Group 0); individuals with at least one child below below 5 (Group 1); individuals with the youngest child between 5 and 9 (Group 2); individuals with the youngest child between 10 and 14 (Group 3); and individuals aged 40 or more with no children younger than 15 present in the family. Individuals on family leave are coded as being out of the labor force. 
Note that the classification of countries into the two groups meets the following formal definition: a country is classified as a permanent withdrawal country if, among all women who dropped out of the labor force after childbirth, the share of women who return to the labor force by the fourth stage of family life (Group 3) is lower than $50 \% .^{24}$ There are three temporary leave countries (France, Germany, and the UK), where - as suggested by the participation profiles - a non-negligible number of women stay out of the labor force until the last stage of family life. However, their share in the total number of women who left the labor force after childbirth is small relative to those who return to the labor force again. There are also several permanent withdrawal countries, such as Ireland or the Netherlands, where some women return to the labor force in Group 2 or later, yet the majority of women who leave the labor force do not come back.

The construction of the labor force participation profiles requires two clarifications. First, as age is only available in five-year bands in our data, the drop in female labor force participation moving from Group 0 to Group 1 reflects the share of women who take family leaves after childbirth as well as the average duration of the family leaves taken. Our definitions of Groups 1-3 are based on the age of the youngest child, so that the length of the family leave, as implied by the depth of the drop in participation, measures the average duration of the career interruption due to one childbirth.

Second, as most of the permanent withdrawal countries have experienced a substantial rise in female labor force participation over the last several decades, the comparison of female participation rates at the first and the last stages of family life may reflect inter-cohort changes rather than individual behavior. ${ }^{25}$ While we cannot disentangle the two by constructing full cohort-based profiles, the data permit us to conduct a simplified cohort analysis which suggests that the shape of the profiles represent within-cohort behavior, and that inter-cohort changes in female labor

\footnotetext{
${ }^{24}$ Formally, $\frac{\left(F L F P_{3}-F L F P_{1}\right)}{\left(F L F P_{0}-F L F P_{1}\right)}<0.50$, where $F L F P_{j}$ is the female labor force participation in group $j$.

${ }^{25}$ Aggregate development in female and male labor force participation rates between 2000-2007 are depicted in Figure A.4 in the Appendix.
} 
force participation only shifts the profiles upwards. ${ }^{26}$ This is also supported by individual-level evidence based on the previous year status reported in EU LFS data, suggesting that the share of currently inactive women out of those who were inactive due to domestic tasks or family responsibilities a year ago exceeds $90 \%$ in the permanent withdrawal countries but ranges between 60 and $85 \%$ among the temporary leave countries.

\section{Female Participation and Unemployment Gaps}

The shape of the female participation profiles corresponds to the differences in the evolution of female unemployment rates and the share of the unemployed among women, as presented in Figure 5. In this section, we focus on the relationship between female labor force participation behavior and gender unemployment gaps. As male unemployment rates are stable across the five stages of family life and do not vary much across countries, we limit our account of the variation in gender unemployment gaps to the variation in female labor force participation and female unemployment rates.

There are four mechanisms that underpin the relationship between female labor force participation and gender unemployment gaps: the effect of family-related career breaks on human capital and productivity; the effect of the anticipation of weak attachment of women to the labor market on individual career decisions and on incentives to statistically discriminate; the discouraged worker effect; and the compositional effect. We discuss them in detail below.

- First, career breaks are detrimental to human capital accumulation and productivity and, therefore, increase the risk of unemployment. Job-protected family leaves have been shown to decrease the mothers' post-leave earnings

\footnotetext{
${ }^{26}$ See Section A.2 in the Appendix. Moreover, note that the inter-cohort changes also affect gender unemployment gaps as the behavior of the previous cohorts of women form a basis for the anticipated future labor force participation behavior of the current cohorts of young women, thus affecting both individual decisions and employers' incentives to statistically discriminate against young women.
} 
and employment (Lalive and Zweimüller 2009; Albrecht et al. 1999; Beblo, Bender, and Wolf 2009). Furthermore, without job protection, family leaves are likely to be followed by spells of unemployment as women have to search for a job first when they return to the labor force. ${ }^{27}$

- Second, the anticipation of substantial family-related career breaks may reduce the incentives of young women to invest in their human capital Weiss and Gronau (1981). Moreover, such anticipation on the employers' side may lead to statistical discrimination. Long statutory family leaves or the high probability of family-related labor force withdrawal will reduce employers incentives to hire young women (evidence surveyed in Darity and Mason 1998 and Blau, Ferber, and Winkler 2010) or to offer them career paths and job training similar to those of men (Puhani and Sonderhof 2011).

- Third, frequent or long unemployment spells reduce the probability of finding a job, which makes a job search more costly and may discourage unemployed women, who have a relatively high reservation wage, from the labor force Blundell, Ham, and Meghir (1998). This so-called discouraged worker effect establishes a link, in which gender unemployment gaps in favor of men reduce the labor force participation of women relative to that of men.

- Fourth, there is what we call the compositional effect, which arises from the fact that the size of the female labor force directly enters the formula of the gender unemployment gap as the denominator in the definition of the female unemployment rate and which has not so far received much attention in the literature. ${ }^{28}$ While the previously listed mechanisms imply a negative correlation between female labor force participation behavior and gender unemployment gaps, the compositional effect can be in any direction, depending

\footnotetext{
${ }^{27}$ This "mechanical" explanation for gender differences in unemployment has been proposed in Johnson (1983).

${ }^{28}$ AGM mention only in a footnote the possibility of a positive selection effect on gender unemployment gaps as an analogy to the gender wage gap case emphasized in Olivetti and Petrongolo (2008).
} 
on the nature of the selection of women into the labor force.

We next consider these four effects as the potential mechanisms that stand behind the unemployment and labor force participation profiles in the temporary leave and the permanent withdrawal countries, as presented above. We first define the compositional effect and then explore its impact as a consequence of labor force withdrawal of women after childbirth, as observed in all the EU countries. We then discuss the indirect evidence of the impact of the remaining three mechanisms for the temporary leave and the permanent withdrawal countries separately.

\subsection{Compositional Effect}

Unemployment rate is defined as the ratio of the unemployed to those in the labor force. It follows that changes in labor force participation, unless accompanied by proportional changes in unemployment, will alter the unemployment rate. The direction and the size of this compositional effect depends on the nature and the extent of the selection of individuals into the labor force.

Selection arises when individuals who participate in the labor force systematically differ in the analyzed outcome from those who are out of the labor force. Positive selection into employment is well-known in the gender wage gap literature. If wages of women who work exceed wages that the non-working women would have if they worked, then the gender wage gap underestimates the true gender wage gap under full participation. This ceteris paribus implies a positive relationship between female participation and gender wage gaps. ${ }^{29}$

Using the same argument, one could expect a similar relationship between female labor force participation and gender unemployment gaps. ${ }^{30}$ We will see, however,

\footnotetext{
${ }^{29}$ Olivetti and Petrongolo (2008) show that almost half of the positive relationship between the observed gender wage gaps and gender employment gaps in OECD countries can be attributed to selection. For the importance of the effect of selection into employment on gender wage gaps see also Hunt (2002); for the effect on wage penalty to "female" occupations see Jurajda and Harmgart (2007).

${ }^{30}$ If women in the labor force have a below-average risk of being unemployed compared to women who are out of the labor force, then countries with a high female labor force participation rate will ceteris paribus have larger gender unemployment gaps, whereas gender unemployment gaps in countries with low female participation will be underestimated.
} 
that the effect of selection into the labor force on gender unemployment gaps is more complex than that on gender wage gaps: first, because of the definition of unemployment, and, second, because it turns out that the selection of women into the labor force may not be always positive.

Let's consider an effect of the change in female labor force on female unemployment rate, and - given our interest in family leaves - let's focus on the labor force withdrawal. When the unemployment rate among women who leave the labor force is lower than the unemployment rate of those who stay, the denominator in the formula for the unemployment rate will be reduced relatively more than the numerator, resulting in an increase in the observed unemployment rate (of those who have stayed in the labor force) driven solely by the labor force withdrawal of those who have left. When the unemployment rate among those who leave is greater than among those who stay, the opposite will be true. Note that the alternative measure of unemployment - the share of unemployed in the population - will be unaffected in the first case and will rise in the second. The first scenario reflects negative selection into the labor force, the second a positive selection into the labor force. ${ }^{31}$ This also implies that gender unemployment gaps in countries with low female participation will be underestimated (relative to the case under full participation) if there is positive selection of women into labor force and overestimated if the selection is negative. ${ }^{32}$

\subsection{Evidence of the Compositional Effect after Childbirth}

At the second stage of family life, the one immediately following childbirth (Group 1), female labor force participation rates plummet, and we observe sizeable gender unemployment gaps in favor of men across the whole EU. In all but seven countries,

\footnotetext{
${ }^{31}$ It is only when the unemployment rate of those who left is the same as those who stayed the case of zero selection - that the female unemployment rate remains unchanged. This can be true only in two cases: if the risk of unemployment is constant across individuals or if selection into the labor force is perfectly random with respect to the unemployment risk.

${ }^{32}$ Provided that the sign of the selection (as determined by the relative magnitude of the observed unemployment rate and the hypothetical unemployment rate among those out of the labor force) is the same across countries.
} 
these gaps are driven by a rise in the female unemployment rate relative to the first stage of family life, which is typically accompanied by no change or fall in the share of unemployed among women. ${ }^{33}$ These patterns fit the consequences of the compositional effect of labor force withdrawal under negative selection into the labor force, suggesting that women who take family leaves after childbirth have lower probability of unemployment (i.e. lower observed unemployment rate) than women who stay in the labor force at that stage. This is not surprising, as only previously employed women (in contrast with their unemployed counterparts) meet the conditions for enjoying the benefits of a statutory family leave, both in terms of pay and job security. ${ }^{34}$ It is also confirmed by the EU LFS data: Based on the information about labor market status in the year preceding the survey, our data suggest that in 19 of the 21 countries, among women who are currently on maternity or parental leave, less than $2 \%$ who were in the labor force a year ago were unemployed. If women who take family leave withdraw predominantly from employment, only the denominator of the unemployment rate is affected, thus increasing the unemployment rate among women in the period immediately following the childbirth but leaving intact the share of unemployed at that period, which is exactly the pattern observed in the data. We conclude that the universal rise across the EU in gender unemployment gaps immediately following childbirth is mostly driven by the compositional effect due to negative selection into labor force as a result of employed women taking family leaves.

\subsection{The Temporary Leave Countries}

As children grow older (Groups 2 and 3), in the temporary leave countries women return to the labor force, which should ceteris paribus drive the female unemployment

\footnotetext{
${ }^{33}$ These seven countries suffer from a high unemployment of youth, which is followed by a decline in both female and male measures of unemployment between the first two stages of family life. The two female unemployment measures, however, diverge from each other and from those of men in a similar way as in the rest of the sample.

${ }^{34}$ Family leave regulations typically require that woman to work for a sufficient long period before childbirth. In addition, the level of maternity leave benefit received is often derived as the percentage of the previous salary.
} 
rate back to its initial level or to the unemployment rate of men (so as to reflect any gender-neutral changes across age groups). Instead, the female unemployment rate declines only slightly, and the share of the unemployed among women rises, which implies that the average risk of unemployment among women who took family leave has increased. This is likely to be a consequence of the effect of a family-related career interruption on women's human capital and productivity, accompanied by the effect of the presence of young children on women's work and job search effort, as well as of the direct transitions from leave to the unemployment of women who return to the labor force but do not have a job. Note that the compositional effect of the increase in the female labor force at the third stage of family life still corresponds to the case of negative selection as the increased average risk of unemployment of women returning to the labor force is still between zero and the unemployment rate among women who have stayed in the labor force. The change in the labor force due to the return of women from family leaves therefore increases the share of the unemployed among women but reduces the female unemployment rate.

Zero or negative gender unemployment gaps in favor of men at the first stage of family life (Group 0) in the temporary leave countries rule out both the gender differences in unobserved pre-market human capital and the statistical discrimination of women driven by the anticipation of family-related career interruptions. The convergence of the labor force participation rates of women and men at the last stage of family life (Group 4) implies that the discouraged worker effect has little importance there, and small or negative gender unemployment gaps at the same stage suggest that there is little persistence in female unemployment rates and the effect of parental leaves gradually fades away. ${ }^{35}$

In terms of cross-country variation among the temporary leave countries, first, we expect that the deeper the drop in female labor force participation in Group 1, the greater the compositional effect of negative selection into the labor force. This

\footnotetext{
${ }^{35}$ As discussed earlier, this is under the assumption that women who do not plan to have children or women above 40 who never had children do not differ from the rest of Group 0 and Group 4 respectively by substantially below-average unemployment risk.
} 
suggests a negative correlation between the female participation rate and the gender unemployment gap and no correlation between the female participation rate and the gender gap in the share of the unemployed among women in Group 1. In the data, the first correlation is -0.60 and statistically significant at the $3 \%$ confidence level and the second correlation is not significant at the $15 \%$ significance level. Second, the longer the family leave, the greater the human capital and productivity loss due to the career break and the higher the risk of unemployment, implying a positive relationship between the duration of family leaves and gender differences in unemployment in Group 2. The actual duration of family leave is not observed in the data but can be imputed as the share of women who drop out of the labor force after childbirth and return at the following stage of family life times five, which captures the five-year age band of the youngest child. ${ }^{36}$ In Group 2, the correlation between the imputed actual family leave duration and gender unemployment gaps is 0.60 and between the actual family leave duration and the gender gap in the share of the unemployed is 0.67 , both statistically significant at the $2 \%$ significance level.

\subsection{The Permanent Withdrawal Countries}

The sizable gender unemployment gaps among young childless individuals in the four Mediterranean countries, where a substantial share of women permanently withdraw from the labor force after childbirth, may result from the fact that the anticipation of weak attachment of women to the labor market in future either lowers women's investments into (unobserved) pre-market human capital or increases employers' incentives to statistically discriminate against young women or both. Similar to the temporary leave countries, part of the gender unemployment gaps at the stage of family life immediately following childbirth (Group 0) is driven by the compositional effect under negative selection. A pattern analogous to the temporary leave participation profiles at the third stage of family life (Group 2)

\footnotetext{
${ }^{36}$ The exact formula for the imputed length of the actual leave is the difference between the female labor force participation rates in Group 2 and Group 1, times 5 (times 60 when expressed in months).
} 
- and the corresponding changes in the female unemployment rate and the share of the unemployed among women - can be detected also among those permanent withdrawal countries, where some women come back to the labor force after their family leaves, but it is almost negligible. Finally, discouraged worker effect is likely to be present in the permanent withdrawal countries, as stages with above average female unemployment rates are followed by stages of stagnation or further decline in female labor force participation, and may, indeed, explain at least part of the permanent withdrawal.

In terms of cross-country variation among the permanent withdrawal countries, the share of women who ultimately remain out of the labor force, as reflected by Group 4, turns out to be the most important for explaining the cross-country variation in gender differences in unemployment. ${ }^{37}$ The weaker the ultimate attachment of women to the labor market, the greater the risk of unemployment at all stages of family life (as a consequence of the anticipation effect on individuals' human capital investments and career decisions, as well as on employer incentives to statistically discriminate), or, in the opposite direction, the greater the gender inequalities in unemployment are across all stages of family life, the lower the female participation rate is in Group 4 (in the case of the discouraged worker effect). In the data, the correlation between female participation rates and gender unemployment gaps in Group 4 is -0.66 , the correlation between female participation rates in Group 4 and the aggregate gender unemployment gaps is -0.64 , both statistically significant at the $10 \%$ significance level.

\section{Underlying Institutions and Social Norms}

As indicated in the introduction, it turns out that the cross-country variation in gender unemployment gaps in the temporary leave countries and in the permanent withdrawal countries can be explained to a great degree by the statutory duration of

\footnotetext{
${ }^{37}$ Note that this rate is below $65 \%$ in all the Mediterranean permanent withdrawal countries except for Portugal, where a relatively high female participation rate is a consequence of a series of external shocks after WW2: colonial war, male emigration in the sixties, and the 1976 revolution.
} 
paid family leave and by the Eurobarometer measure of perceived prevalence of gender discrimination, respectively. ${ }^{38}$ In this section, we first present our explanation of the cross-country variation in gender unemployment gaps within a simple regression framework. We then focus on the two explanatory factors and provide evidence of their behavioral impact, which leads to the observed cross-country variation in gender unemployment gaps.

\subsection{Gender Unemployment Gaps "Explained"}

We use gender unemployment gaps adjusted for gender differences in pre-market human capital in our explanation and, as suggested by the data, focus separately on individuals with children below 15 and those without. We divide the sample into the temporary leave and permanent withdrawal countries and relate the premarket human capital adjusted gender unemployment gaps to the two factors, the statutory duration of paid family leave and the perceived gender discrimination, respectively. Figure 7 shows that while the statutory duration of paid family leave explains $53.8 \%$ of the variation in gender unemployment gaps among individuals with children in the temporary leave countries, this institutional factor has zero explanatory power for cross-country differences in gender unemployment gaps in the permanent withdrawal countries. On the other hand, the perceived prevalence of gender discrimination is strongly positively correlated with gender unemployment gaps both among individuals with and without children younger than 15 in the permanent withdrawal countries $\left(R^{2}=0.74\right.$ and $\left.R^{2}=0.53\right)$ but is unrelated to the gender differences in unemployment among individuals in the temporary leave countries irrespective of the presence of children. ${ }^{39}$ The three relationships clearly cannot be interpreted as causal due to the potential endogeneity of family leave duration and perceived gender discrimination. The very low explanatory power that each of the two institutional factors has for the cross-country variation in

\footnotetext{
${ }^{38}$ See Sections A.1.2 and A.1.3 in the Appendix for the exact definitions and sources.

${ }^{39}$ Note that we do not propose any explanatory factor for the variation in gender unemployment gaps among individuals without children younger than 15 in the temporary leave countries as there are almost no gaps in favor of men and not much variation to explain.
} 
gender unemployment gaps in the other group of countries suggests, however, that the endogeneity would have to be specific to a particular country type, which seems unlikely.

When we combine all the steps of our proposed explanation into a single regression, using a sample of 40 gender unemployment gaps, i.e., two observations per country (among individuals with and without children below 15) with four explanatory variables plus a constant, the goodness of fit measures are $R^{2}=0.79$ and Adjusted $R^{2}=0.77$ respectively. ${ }^{40}$

The four explanatory variables are: a binary indicator whether the country belongs among the temporary leave countries, an interaction of the statutory duration of paid family leave with an indicator for individuals with children in the temporary leave countries, an interaction of perceived prevalence of gender discrimination with an indicator for individuals with children in the permanent withdrawal countries, and an interaction of perceived prevalence of gender discrimination and an indicator for individuals without children in the permanent withdrawal countries. ${ }^{41}$

We therefore explain $80 \%$ of the cross-country variation in gender unemployment gaps adjusted for gender differences in pre-market human capital by focusing separately on individuals with children below 15 and those without, by dividing the sample into temporary leave and permanent withdrawal countries, and by applying a single explanatory factor, a different one in each group. ${ }^{42}$ We next present direct evidence of the impact of the two factors on individuals' behavior.

\footnotetext{
${ }^{40}$ As information about the degree of prevalence of gender discrimination for Hungary is missing, there are only 20 countries and 40 data points in this regression.

${ }^{41}$ Regression with full interactions among the two binary indicators (for the type of country and for the presence of children) and with the two explanatory factors (statutory duration of paid family leave and the perceived prevalence of gender discrimination) renders $R^{2}=0.81$ and Adjusted $R^{2}=0.75$, respectively. We arrive at the final specification presented in the text by dropping the statistically insignificant variables, which leaves us only with the ones which are part of our proposed explanation.

${ }^{42}$ Given the negligible role of pre-market human capital differences, the results for the adjusted and unadjusted gaps are fairly similar: Using the same specification, we are able to explain $68 \%$ of the variation in unadjusted gender unemployment gaps. See also Figure A.2 with unadjusted gender unemployment gaps on the y-axis in section A.4 of the Appendix.
} 
Figure 7: Gender Unemployment Gaps in the EU "Explained"

\section{Pre-market Human Capital Adjusted Gender Unemployment Gap (in p.p.)}
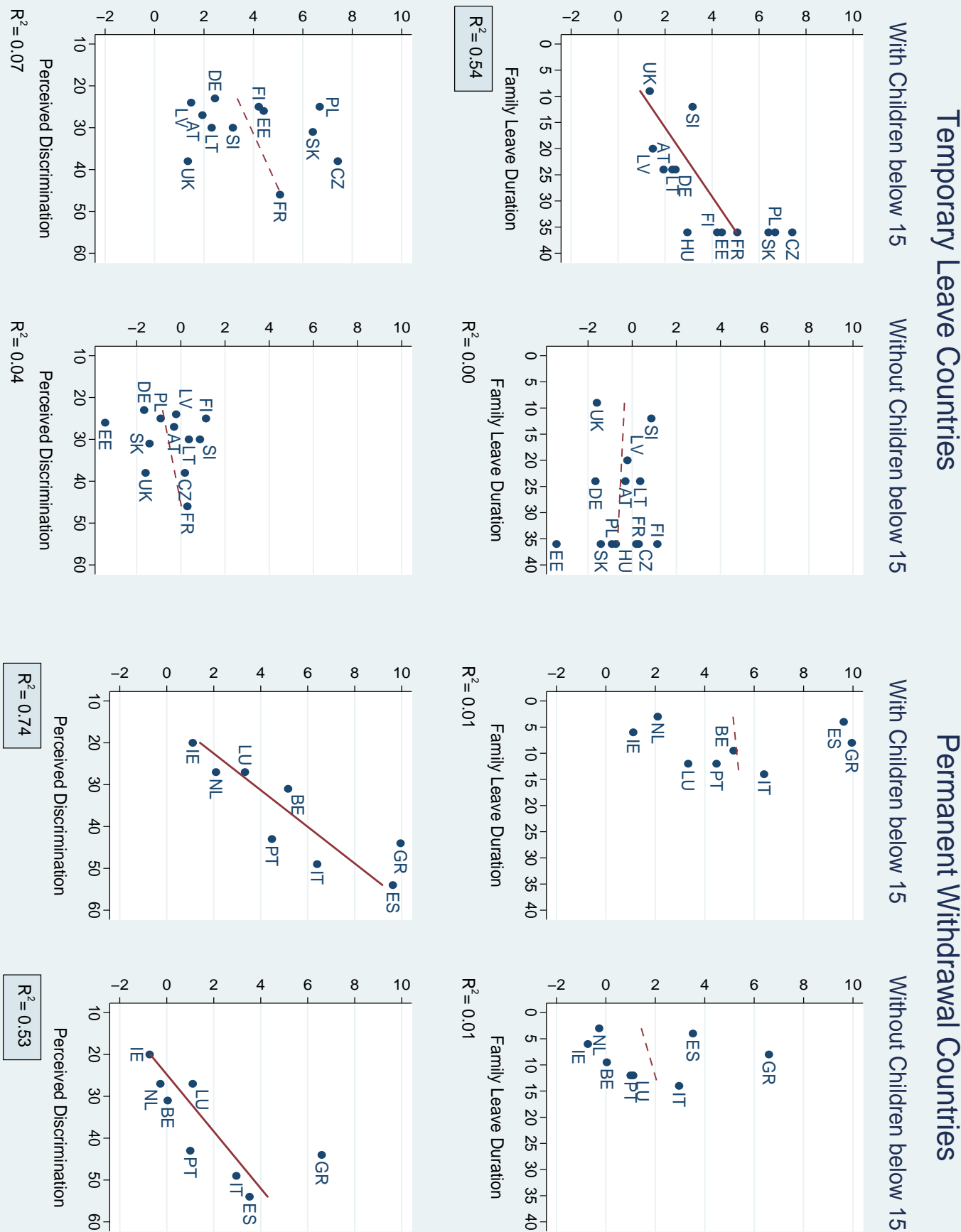

Note: EU LFS data. Own calculations. Five-year averages of gender unemployment gaps among prime age individuals, constructed using sampling weights, over 2003-2007. Gender unemployment gaps (in p.p.) are adjusted for gender differences in pre-market human capital using a flexible version of the Oaxaca-Blinder decomposition. Family leave duration is the maximum duration of total paid postnatal leave in months. Source: The Council of Europe Family Policy Database. Perceived gender discrimination is measured as the share of all respondents who perceive gender discrimination as widespread in their country. Source: Eurobarometer 2008. Straight lines show a fit from OLS regressions of gender unemployment gaps on a constant and the respective right-hand side variables. 


\subsection{Family Leave}

Figure 8 maps the actual family leave duration, imputed from the data as defined earlier, to the statutory norm. The $R^{2}$ of 0.60 from a regression of the actual family leave duration on a constant and the duration of the statutory paid family leave suggests a close correspondence between the behavior and the institution. Note that

Figure 8: Actual Family Leave Duration and Total Paid Family Leave

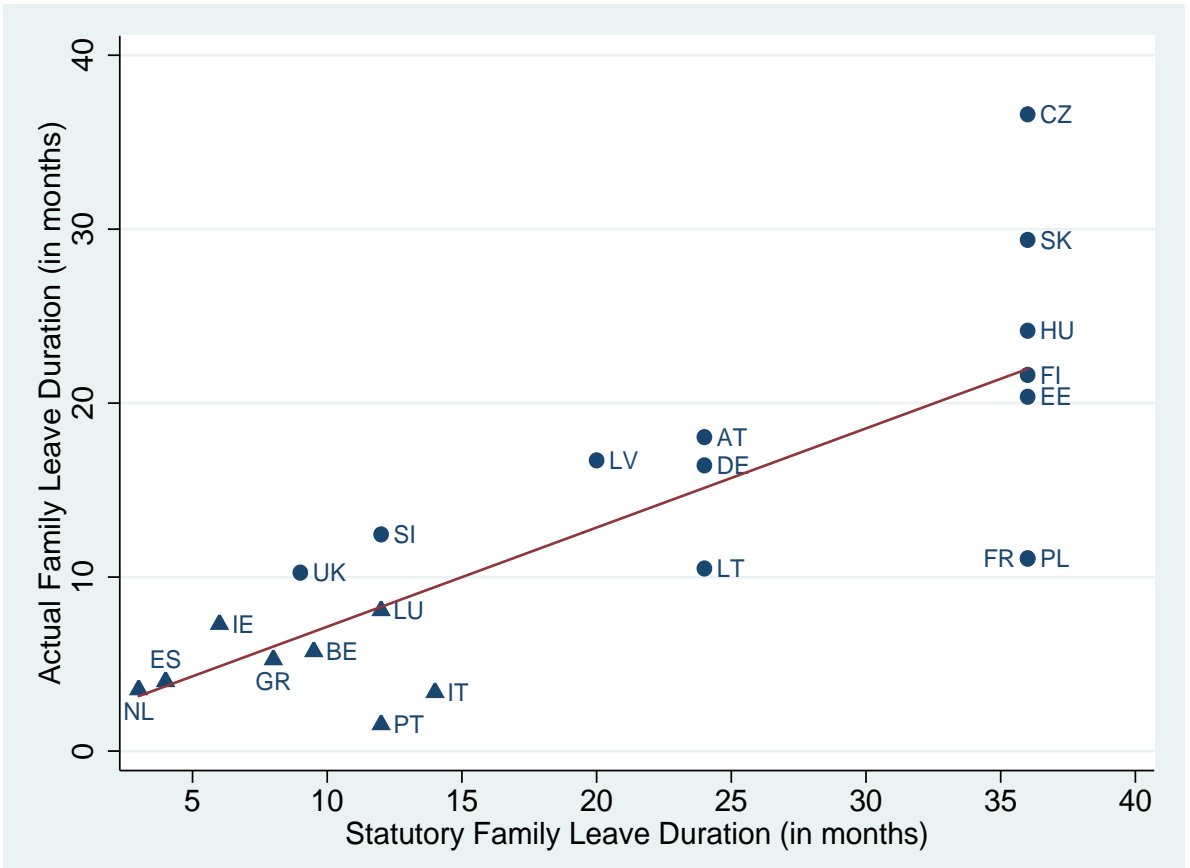

Note: Actual leave is imputed from the EU LFS data as the difference between the 5-year averaged (over 2003-2007) female labor force participation rate in Group 2 and Group 1, times 60. Annual participation rates (of prime age individuals) are constructed using sampling weights. Statutory duration of paid family leave is the maximum duration of total paid postnatal leave in months from The Council of Europe Family Policy Database. Permanent withdrawal countries are marked by a triangle; temporary leave countries are marked by a circle.

the permanent withdrawal countries (indicated by a triangular marker) concentrate in the lower left corner: as women there do not have an option of a temporary paid and job-protected family-related career break, they either take very short family leaves or - rather - they leave the labor force permanently. ${ }^{43}$ Algan and Cahuc (2006) find that in the Mediterranean countries, as well as in some countries of continental Europe including Belgium and the Netherlands, almost two-thirds of respondents agree with the statement that "A preschool child suffers if the mother

\footnotetext{
${ }^{43}$ The actual family leaves in permanent withdrawal countries are short by construction as only very few women who leave the labor force after childbirth in Group 1 come back in Group 2.
} 
works," suggesting that the traditional perception of motherhood is widespread among the permanent withdrawal countries. Such perception of motherhood is likely to contribute to the absence of family leave policies supporting mothers' return to the labor force, as well as to permanent labor force withdrawal.

\subsection{Prevalence of Gender Discrimination}

The size of gender unemployment gaps in the permanent withdrawal countries closely corresponds to the extent of gender discrimination perceived by Eurobarometer survey respondents (as shown in Figure 7). There are several ways of interpreting the Eurobarometer measure of the perceived prevalence of gender discrimination and its relationship with gender unemployment gaps. First scenario: respondents have a better knowledge of individual productivity and instances of discrimination than a researcher, so that the Eurobarometer measure reveals true discrimination as a source of gender unemployment gaps. Second scenario: respondents do not correctly condition on individual characteristics and productivity, and therefore misclassify unequal treatment due to real gender differences in productivity as discrimination, in which case gender unemployment gaps as well as the perceived gender discrimination may still be a consequence of unobserved gender differences in human capital and productivity. Third scenario: the respondents' answers are based on aggregate statistics such as gender unemployment gaps, suggesting a reversed causality between the gender differences in unemployment and the perceived prevalence of discrimination. While the last case is a plausible explanation, if it was true we would expect a perceived prevalence of gender discrimination to explain observed cross-country variation in gender unemployment gaps among the temporary leave countries as well, which it does not. This leaves us with gender discrimination and gender differences in unobserved human capital as the two candidate explanations.

The permanent withdrawal countries can be divided into two groups with respect to the occurrence of gender unemployment gaps across the five stages of family life. While in Ireland and the Benelux countries gender unemployment gaps are almost 
only among individuals with children below 15, in the Mediterranean countries there are gender differences in unemployment also among young childless women and among women over 40 without children in the family. The presence of gender unemployment gaps among the young and childless may be again driven either by gender differences in unobserved pre-market human capital and career choices or by gender discrimination. ${ }^{44}$ As nothing else can be revealed from our data about the potential gender differences in unobserved pre-market human capital, we next focus on true gender discrimination as the interpretation of the Eurobarometer measure and try to give this notion a more specific content.

So far, we have considered only statistical discrimination, when weak labor force attachment of women from previous cohorts is interpreted by the employers as a signal of future labor force participation of the current cohort of young women. Gender differences in unemployment may also be a consequence of taste-based discrimination arising from gender stereotypes rooted in traditional family culture, associated by Algan and Cahuc (2005) with Catholicism or Greek Orthodoxy. With the exception of the Netherlands, the permanent withdrawal countries have the highest share of Catholics (or the Greek Orthodox in Greece) in the population in the EU. Fortin (2005) and AGM find a positive relationship between the prevalence of the belief that "when jobs are scarce, men should have more right to a job than women" and gender differences in labor market outcomes. Using a more recent measure of "prejudice", namely the share of men that agree with the above statement in the European and World Values Surveys in 1999, we find that the correlation between prejudice and the perceived prevalence of gender discrimination among the permanent withdrawal countries is $0.52 .{ }^{45}$

Algan and Cahuc (2006) argue that traditional gender role attitudes may give rise to job protection policies that favor traditional full-time male employment but are detrimental for female employment. Kahn (2007) finds that employment

\footnotetext{
${ }^{44}$ Note that the former may also be a consequence of the latter, if individuals' decisions about human capital investments and career choices are affected by the expectations driven by the prevailing unequal treatment of women and men in the labor market.

${ }^{45}$ See Appendix for the additional data source and the exact definition of prejudice.
} 
protection laws increase the incidence of temporary employment among women, which is likely to increase their job insecurity. The left panel of Figure 9 shows that the size of the gender gap in the share of permanent contracts, as constructed from EU LFS data and defined as the difference between the shares of permanent contracts (among all work contracts) of men and women, is positively related to the perceived prevalence of gender discrimination in the permanent withdrawal countries. Note that gender differences in the incidence of permanent contracts among working prime age individuals exceed 3.5 p.p. in three of the Mediterranean countries as well as in Belgium. While segregation of women into jobs with fixedterm contracts may also be driven by their preferences, Petrongolo (2004) shows that women in Southern Europe, despite having the same productivity as men, are involuntarily overrepresented in fixed-term employment contracts, and interprets her finding as indirect evidence of gender discrimination.

Figure 9: Gender Discrimination and Employment Contracts

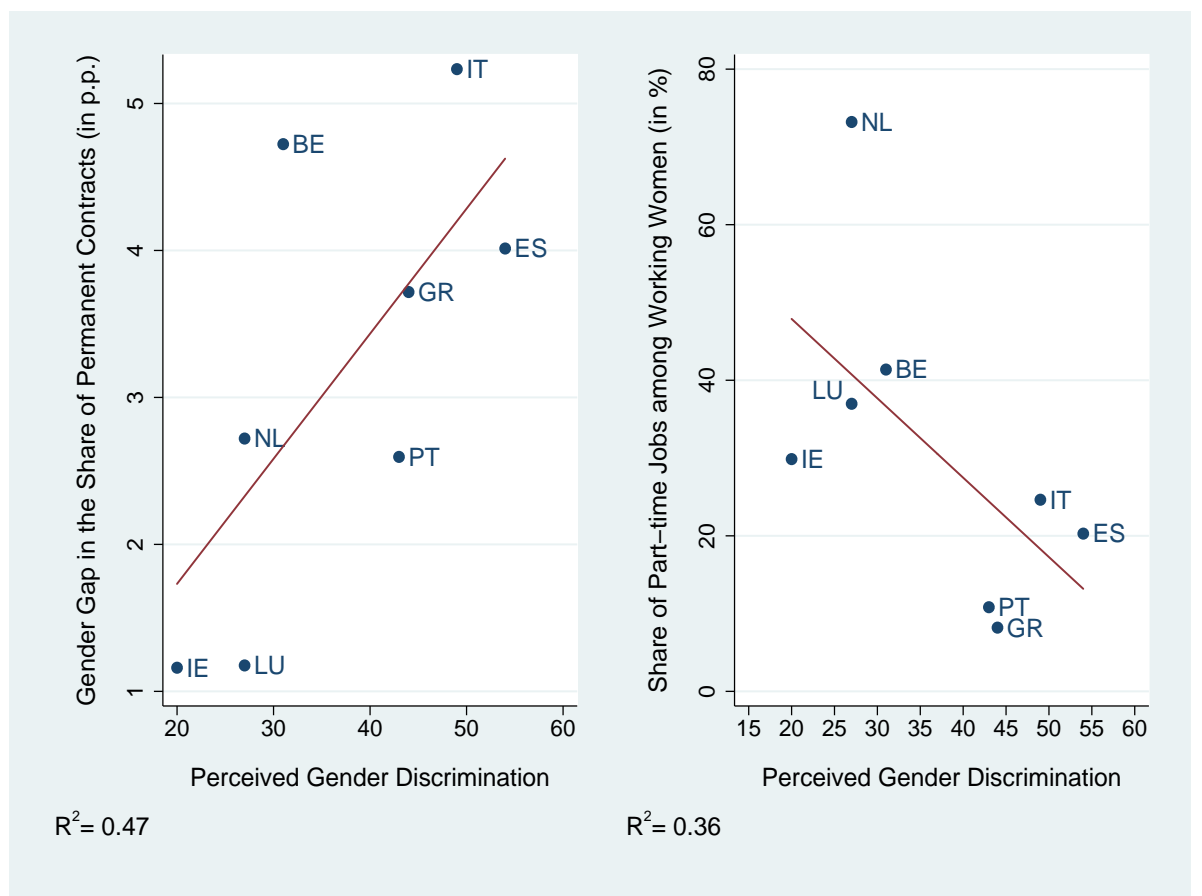

Note: Perceived gender discrimination is a share of all respondents who perceive gender discrimination as widespread in their country (from the Eurobarometer survey in 2008). The Y-axis on the left panel shows the difference between the shares of permanent contracts (among all work contracts) of men and women (in p.p.). The Y-axis on the right panel shows the share of part-time jobs among women who work (in \%). Both measures are computed from annual EU LFS data for prime age individuals using sampling weights and averaged over 2003-2007. 
Flexible working conditions, on the other hand, help women combine work and family, allowing them to stay attached to the labor market and maintain their human capital when their children are young (Kahn 2007). The right panel of Figure 9 shows an inverse relationship between the incidence of part-time jobs among women, constructed from EU LFS data, and the perceived prevalence of gender discrimination in the permanent withdrawal countries. While the share of part-time jobs among working prime age women exceeds $40 \%$ in Belgium and the Netherlands, it is below $25 \%$ in the four Mediterranean countries. ${ }^{46}$

\section{Conclusion}

Focusing on the cross-country variation in gender unemployment gaps in the European Union, we show that in a majority of countries, gender differences in unemployment exist only among individuals with children and result from above-average female unemployment rates of mothers when compared to men and to women without children in the family.

Female unemployment rates, in turn, are closely related to female labor force participation profiles across the five stages of family life, given by age, fertility status and the age of children. The sharp drop in female labor force participation after childbirth coincides with a sharp rise in the female unemployment rate. As there is no change in the share of the unemployed in the female population at that stage, we attribute this rise purely to the compositional change in the labor force. When women return to the labor force after family leave, the share of the unemployed rises towards the unemployment rate in the female population at this particular stage. We suggest that the effect of family leave on human capital and productivity as well as the mechanical effect of direct transition to unemployment when family leave is not job-protected are the most likely driving forces behind this pattern.

\footnotetext{
${ }^{46}$ It is interesting that the overrepresentation of women in the small share of part-time jobs that exist in Southern Europe is also involuntary in contrast to the other EU countries (Petrongolo 2004). This seems to imply that while in countries like the Netherlands, the widespread use of part-time jobs helps women combine work and family, the scarce part-time jobs in Mediterranean countries are likely to serve employers as tools for gender discrimination.
} 
Based on female labor force participation behavior across the five stages of family life we divide the 21 countries into two groups: 13 temporary leave countries, where the majority of women take family leaves of various lengths after childbirth and then return to the labor force, and 8 permanent withdrawal countries, where the shape of the participation profiles suggests that the majority of women who leave the labor force after childbirth never return.

Turning to the underlying institutions, we find that the length of the statutory paid family leave can explain almost half of the cross-country variation in gender unemployment gaps among the temporary leave countries, but none of the variation among the permanent withdrawal countries, which have only very short or no paid family leaves. While gender role attitudes rooted in traditional family culture seem widespread among most of the permanent withdrawal countries, the perceived prevalence of gender discrimination varies substantially and turns out to be strongly positively correlated with the size of gender unemployment gaps there.

While the two unilateral relationships cannot be interpreted as causal, they complement and support the main conclusions that follow from our decomposition results. First, decomposition of gender unemployment gaps across the five stages of family life points at the duration of women's career breaks after childbirth as the key determinant of the above-average unemployment rates among mothers with young children. The strong correlation between the statutory duration of paid family leave and gender unemployment gaps reveals the importance of the underlying institution. Second, the high explanatory power of the prevalence of gender discrimination offers a likely interpretation of gender unemployment gaps among young childless individuals, which exist only in four Mediterranean permanent withdrawal countries.

Finally, both findings are in line with the empirical evidence documented in previous literature (based on a single-country quasi-natural experiments or a panel data estimation using a small group of countries) on the effect of the duration of paid family leave on employment (Lalive and Zweimüller 2009) and the presence of gender discrimination in the Mediterranean countries (Petrongolo 2004). While 
a similar difference-in-differences estimation design could in principle be set up for the 21 countries used here, high inertia of the two factors over the period for which the EU LFS data is available would limit the identification of their effects to only very few countries. In addition, both factors are likely to be endogenous and the lack of suitable instruments would further undermine the causal interpretation of the estimated effects.

This paper proposes a data-driven explanation of $80 \%$ of the cross-country variation in gender unemployment gaps in the $21 \mathrm{EU}$ countries: by adjusting gender unemployment gaps for gender differences in pre-market human capital, by focusing separately on individuals with children below 15 and those without, by dividing the sample into temporary leave and permanent withdrawal countries and by applying a single explanatory factor, the statutory duration of paid family leave in the first group and the prevalence of gender discrimination in the other. Our findings should serve as a starting point for future research focused on the identification of the causality in the proposed relationships and on their policy implications.

\section{References}

Adsera, A. 2005. "Vanishing Children: From High Unemployment to Low Fertility in Developed Countries." American Economic Review 95 (2): 189-193.

Albrecht, J. W., P. A. Edin, M. Sundström, and S. B. Vroman. 1999. "Career

Interruptions and Subsequent Earnings: A Reexamination Using Swedish Data." Journal of Human Resources 34 (2): 294-311.

Algan, Y., and P. Cahuc. 2005. "The Roots of Low European Employment: Family Culture?" In NBER International Seminar on Macroeconomics 2005, NBER Chapters. National Bureau of Economic Research, Inc.

. 2006. "Job Protection: The Macho Hypothesis." Oxford Review of Economic Policy 22 (3): 390-410.

Altonji, J.G., and R.M. Blank. 1999. "Race and Gender in the Labor Market." 
Chapter 48 of Handbook of Labor Economics, edited by O. Ashenfelter and D.Card, Volume 3, 1, 3143-3259. Elsevier.

Azmat, G., M. Güell, and A. Manning. 2006. "Gender Gaps in Unemployment Rates in OECD Countries." Journal of Labor Economics 24 (1): 1-38.

Beblo, M., S. Bender, and E. Wolf. 2009. "Establishment-level Wage Effects of Entering Motherhood." Oxford Economic Papers 61:i11-i34.

Becker, Gary S. 1985. "Human Capital, Effort, and the Sexual Division of Labor." Journal of Labor Economics 3 (1): S33-58.

Benati, L. 2001. "Some Empirical Evidence on the 'Discouraged Worker' Effect." Economics Letters 70 (3): 387-395.

Bertola, G., F. Blau, and L. Kahn. 2007. "Labor Market Institutions and Demographic Employment Patterns." Journal of Population Economics 20 (4): 833-867.

Blau, F., M. Ferber, and A. Winkler. 2010. The Economics of Women, Men, and Work. 6. Prentice-Hall.

Blau, F. D., and L. M. Kahn. 2003. "Understanding International Differences in the Gender Pay Gap." Journal of Labor Economics 21 (1): 106-144.

Blundell, R., J. Ham, and C. Meghir. 1998. "Unemployment, Discouraged Workers and Female Labour Supply." Research in Economics 52 (2): 103-131.

Brandolini, A., P. Cipollone, and E. Viviano. 2006. "Does the ILO Definition Capture All Unemployment?" Journal of the European Economic Association 4 (1): $153-179$.

Clark, A. E., and A.J. Oswald. 1994. "Unhappiness and Unemployment." Economic Journal 104 (424): 648-59.

Darity, W., and P. Mason. 1998. "Evidence on Discrimination in Employment: Codes of Color, Codes of Gender." Journal of Economic Perspectives 12 (2): 63-90. 
Eliason, M., and D. Storrie. 2006. "Lasting or Latent Scars? Swedish Evidence on the Long-Term Effects of Job Displacement." Journal of Labor Economics 24 (4): 831-856.

Fortin, N. M. 2005. "Gender Role Attitudes and the Labour-market Outcomes of Women across OECD Countries." Oxford Review of Economic Policy 21 (3): 416-438.

Ginther, D. K., and M. Zavodny. 2001. "Is the Male Marriage Premium due to Selection? The Effect of Shotgun Weddings on the Return to Marriage." Journal of Population Economics 14 (2): 313-328.

Hunt, J. 2002. "The Transition in East Germany: When Is a Ten-Point Fall in the Gender Wage Gap Bad News?" Journal of Labor Economics 20 (1): 148-169.

Jacobson, L. S., R. J. LaLonde, and D. G. Sullivan. 1993. "Earnings Losses of Displaced Workers." American Economic Review 83 (4): 685-709.

Johnson, J. L. 1983. "Sex Differentials in Unemployment Rates: A Case for No Concern." Journal of Political Economy 91 (2): 293-303.

Jones, S. R. G., and W. C. Riddell. 1999. "The Measurement of Unemployment: An Empirical Approach." Econometrica 67 (1): 147-162.

Jurajda, S., and H. Harmgart. 2007. "When do Female Occupations Pay More?" Journal of Comparative Economics 35 (1): 170-187.

Kahn, L. M. 2007. "The Impact of Employment Protection Mandates on Demographic Temporary Employment Patterns: International Microeconomic Evidence." Economic Journal 117 (521): 333-356.

Korenman, S., and D. Neumark. 1991. "Does Marriage Really Make Men More Productive?" Journal of Human Resources 26 (2): 282-307.

Lalive, R., and J. Zweimüller. 2009. "How does Parental Leave Affect Fertility and Return to Work? Evidence from Two Natural Experiments." The Quarterly Journal of Economics 124 (3): 1363-1402. 
Mincer, J. 1993. "Education and Unemployment." Chapter 7 of Studies in Human Capital, edited by J. Mincer, Volume 1, 1, 212-238. Edward Elgar.

Nopo, H. 2008. "Matching as a Tool to Decompose Wage Gaps." The Review of Economics and Statistics 90 (2): 290-299.

OECD. 2002. Employment Outlook 2002.

—. 2008. Employment Outlook 2008.

Olivetti, C., and B. Petrongolo. 2008. "Unequal Pay or Unequal Employment? A Cross-Country Analysis of Gender Gaps." Journal of Labor Economics 26 (4): 621-654 (October).

Petrongolo, B. 2004. "Gender Segregation in Employment Contracts." Journal of the European Economic Association 2 (2-3): 331-345.

Puhani, P., and K. Sonderhof. 2011. "The Effects of Parental Leave Extension on Training for Young Women." Journal of Population Economics 24 (2): $731-760$

Weichselbaumer, D., and R. Winter-Ebmer. 2005. "A Meta-Analysis of the International Gender Wage Gap." Journal of Economic Surveys 19 (3): 479 511.

2007. "The Effects of Competition and Equal Treatment Laws on Gender Wage Differentials." Economic Policy 22:235-287.

Weiss, Y., and R. Gronau. 1981. "Expected Interruptions in Labour Force Participation and Sex-Related Differences in Earnings Growth." Review of Economic Studies 48 (4): 607-19. 


\section{A Appendix}

\section{A.1 Data Sources and Sample Size}

\section{A.1.1 EU LFS Data}

Our data are comprised of 21 national labor force surveys conducted by the national statistical institutes across Europe and centrally processed by Eurostat into the European Union Labor Force Survey Data. ${ }^{47}$ We focus on prime age individuals (between 25-54 years old) with the sample size for respective country-years provided in Table A.1. Substantial changes in the sample size in some of the countries are

Table A.1: Sample Size

\begin{tabular}{|l|r|r|r|r|r|r|r|}
\hline Country & 2001 & 2002 & 2003 & 2004 & 2005 & 2006 & 2007 \\
\hline \hline Austria & 25217 & 24770 & 23539 & 19338 & 21933 & 21526 & 21848 \\
Belgium & 10333 & 11770 & 11549 & 12289 & 12172 & 12148 & 11637 \\
Czech Republic & 24919 & 26254 & 25678 & 26265 & 25929 & 25915 & 25639 \\
Estonia & 2097 & 1979 & 1942 & 1823 & 1777 & 2035 & 2405 \\
Finland & 17410 & 17217 & 16670 & 16032 & 15628 & 14967 & 14739 \\
France & 74362 & 72526 & 35522 & 35340 & 34866 & 33239 & 34812 \\
Germany & & 138646 & 139676 & 137609 & 71044 & 6747 & 4175 \\
Greece & 32404 & 31049 & 29244 & 33202 & 32243 & 30954 & 29745 \\
Hungary & 34500 & 34003 & 36993 & 34517 & 32109 & 31727 & 31333 \\
Ireland & 42766 & 43372 & 41651 & 35395 & 37441 & 35381 & 34905 \\
Italy & 84716 & 83354 & 81599 & 71373 & 72972 & 70056 & 68244 \\
Latvia & 7535 & 2461 & 2445 & 2504 & 2310 & 1918 & 3565 \\
Lithuania & 3899 & 5404 & 5043 & 5085 & 4991 & 4566 & 7148 \\
Luxembourg & 6439 & 5715 & 7089 & 9194 & 9765 & 9373 & 2206 \\
Netherlands & 44642 & 47773 & 46826 & 54695 & 55073 & 56644 & 51300 \\
Poland & 24195 & 24421 & 24464 & 24075 & 23066 & 22208 & 21023 \\
Portugal & 17528 & 17507 & 18265 & 20772 & 19386 & 17825 & 16903 \\
Slovakia & 12867 & 12190 & 12274 & 12058 & 12122 & 11897 & 11409 \\
Slovenia & 8976 & 9074 & 9255 & 8658 & 8139 & 7830 & 7642 \\
Spain & 72175 & 72307 & 73771 & 74186 & 65892 & 69103 & 71495 \\
United Kingdom & 56294 & 56168 & 53074 & 50490 & 49589 & 48318 & 47712 \\
\hline \hline Note: EU LFS, prima
\end{tabular}

Note: EU LFS, prime age individuals (25-54 year olds), conscripts excluded.

driven by a change in the underlying national labor force survey included as part of the EU LFS data. To avoid any potential discontinuities and to smooth any business cycle effects, the main analysis is based on 5-year averages from years 2003-2007 for the whole sample, except for the averages for years 2004-2007 in Austria and years 2006-2007 in Finland. ${ }^{48}$

\footnotetext{
${ }^{47}$ The exact reference is: European Commission, Eurostat, the 2008 release of the anonymised European Union Labor Force Survey datasets for the reference years 2001-2007. We use Spring data (from Quarter 2) only to ensure comparability across years. The Eurostat has no responsibility for the results and conclusions presented in this paper.

${ }^{48}$ Children cannot be linked to their parents for all the countries and years in the data, but the presence of individuals younger than 15 years old in the typical family with only one or two prime age household members makes parenthood very likely. Note that information about children and their age is incomplete or missing in Ireland in the years 2003-2005 and in Italy for 2004. Whenever
} 


\section{A.1.2 Duration of the Statutory Family Leaves}

We use the maximum duration of paid family leave (including both maternity and parental leave), after which women can return to their jobs, from The Council of Europe Family Policy Database, Figure 13 in Part 3.3. This measure proves to be the most important for individual behavior when compared to alternative measures such as the duration of high paid leave with benefits above $70 \%$ of the salary, or the total duration of family leave irrespective of whether paid. There are three cases in which we deviate from Figure 13 of The Council of Europe Family Policy Database: First, we take the duration of 36 months instead of 24 in France and Poland, where the earlier is for the second and subsequent child. Note also that the paid family leave in Poland is means-tested. Second, we take the duration of 24 months in Germany instead of 12 as the 12-month paid parental leave there can be increased to 24 months with proportional reduction of the amount paid. In other words, for countries where the length of the statutory paid family leave varies, we always take the longest possible paid family leave duration. The actual family leave duration imputed from the data confirms our choice of the measure of the duration of statutory family leave.

While paternity leave legislation also varies across countries, the statutory length as well as actual duration and occurrence of family leaves taken by fathers is negligible compared to those taken by women, and their cross-country variation does not add much to our proposed explanation of gender unemployment gaps.

\section{A.1.3 Discrimination and Prejudice Measures}

Perceived gender discrimination comes from the Eurobarometer survey in 2008 and is measured as the share of all respondents who perceive gender discrimination as widespread in their country. We measure prejudice against women by the share of men that agree with the statement that when jobs are scarce, men should have more right to a job than women, as measured by the 1999 European and World Values Survey.

\section{A.2 Cohort Analysis}

The profiles we present in the text match individuals either by age group or by a duration from the last childbirth. Cohort profiles are in many respects superior to age-based profiles when we discuss individual behavior, in particular among the permanent withdrawal countries, where female participation has been rising over the

we disaggregate the data by the five stages of family life, these country-years are omitted from the analysis. 
Figure A.1: Female Labor Force Participation Profiles across Cohorts
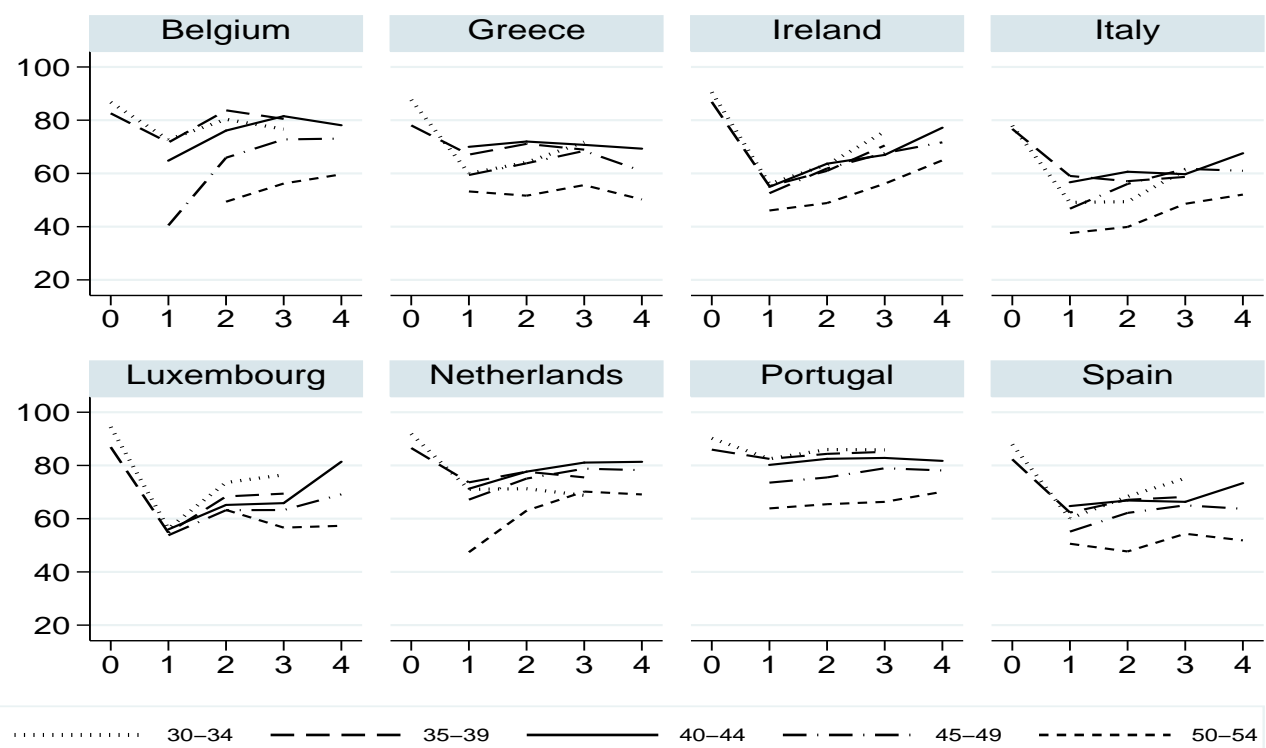

[0] Age $<40$, No Child, [1] Child $<5$, [2] Child 5 to 9, [3] Child 10 to 14, [4] Age $=>40$, No Child

Note: EU LFS data, sample of individuals 30-54 years old. Weighted by sampling weights. Cells with less than 50 observations are excluded. The most recent cohort of 25-29 year-olds is also omitted as it is only observed at later stages of family life when the last childbirth occurred before the age of 18, which makes the shape of the profile non-representative of the population. The five stages of family life are defined as follows: individuals younger than 40 with no children younger than 15 in the family (Group 0); individuals with at least one child below 5 (Group 1); individuals with the youngest child between 5 and 9 (Group 2); individuals with the youngest child between 10 and 14 (Group 3); and individuals aged 40 or more with no children younger than 15 present in the family.

studied period and could lead to the observed permanent withdrawal pattern across cohorts. Unfortunately, pseudo-panel data at cohort level cannot be constructed from five years of data, where age information is available only in 5-year age bands. However, the timing of childbirth provides us with the necessary variation in the data that enables us - at least to some extent - to explore the role of cohort effects in our analysis: Figure A.1 presents the labor force participation profiles of women from the same age group (a 5-year band between 2003 and 2007) over the five stages of family life. Clearly, for some "cohorts", the first and the last stage of family life cannot be populated, as it is defined by age. It is, however, the evolution across the three stages defined by the age of the last child which is the most important for our argument, and which shows that rising female participation among the permanent withdrawal countries has been shifting the profiles upwards while their shape remained relatively stable.

\section{A.3 A Comparison with Azmat, Güell, and Manning (2006)}

AGM is the closest antecedent of this paper, the main differences between their study and ours are listed below. In terms of data, we provide evidence about 21 EU countries including the New EU member states for the period of 2003-2007, 
compared with 14 West European countries and the US in the second half of the 1990s in AGM. As a collection of standardized national labor force surveys, EU LFS data is superior to ECHP in terms of the sample size and representativeness.

Based on a series of country-level probit models of the probability to be unemployed as a function of standard individual characteristics, AGM conclude that gender differences in human capital accumulation are the main factor that leads to gender unemployment gaps. They further ask what drives the observed crosscountry variation in gender unemployment gaps and suggest that in addition to family policies, labor market institutions that affect wage flexibility and labor turnover may play an important role. They also note that gender unemployment gaps also positively correlate with the degree of prejudice about men's priority claim for a job. While our results are consistent with AGM's findings, our data decomposition by the five stages of family life offers additional insights, which lead us to the parsimonious account of $80 \%$ of the cross-country variation in gender unemployment gaps by dividing EU into two groups, based on a typical labor force participation behavior of women after childbirth, and finding a single explanatory factor for each group.

While we were able to qualitatively replicate the results from probit models estimated by AGM using our data, we decided to omit their voluminous regression output, as it did not bring substantively more insight on top of what we present and the length of the paper would double. A previous version of this paper also contained an analysis of transitions between labor market states in two subsequent years, similar to the one carried out in AGM. For the sake of comparison, we only mention here the main findings, which support - but are not crucial for - our main results: Similar to AGM, we find that gender differences in the flows between employment and unemployment are responsible for the gender unemployment gaps at all stages of family life in the permanent withdrawal countries, and among individuals with young children among the temporary leave countries. In contrast to AGM, who conclude that transitions into and out of the labor force do not contribute to gender unemployment gaps, two of the flows between unemployment and inactivity turn out to be important in our data: First, a high share of women moves directly from family leave into unemployment; and second, in some of the permanent withdrawal countries, women move from unemployment into inactivity substantially more often than men. 


\section{A.4 Supplementary Figures}

Figure A.2: Gender Unemployment Gaps in EU "Explained"

\section{Gender Unemployment Gap (in p.p.)}
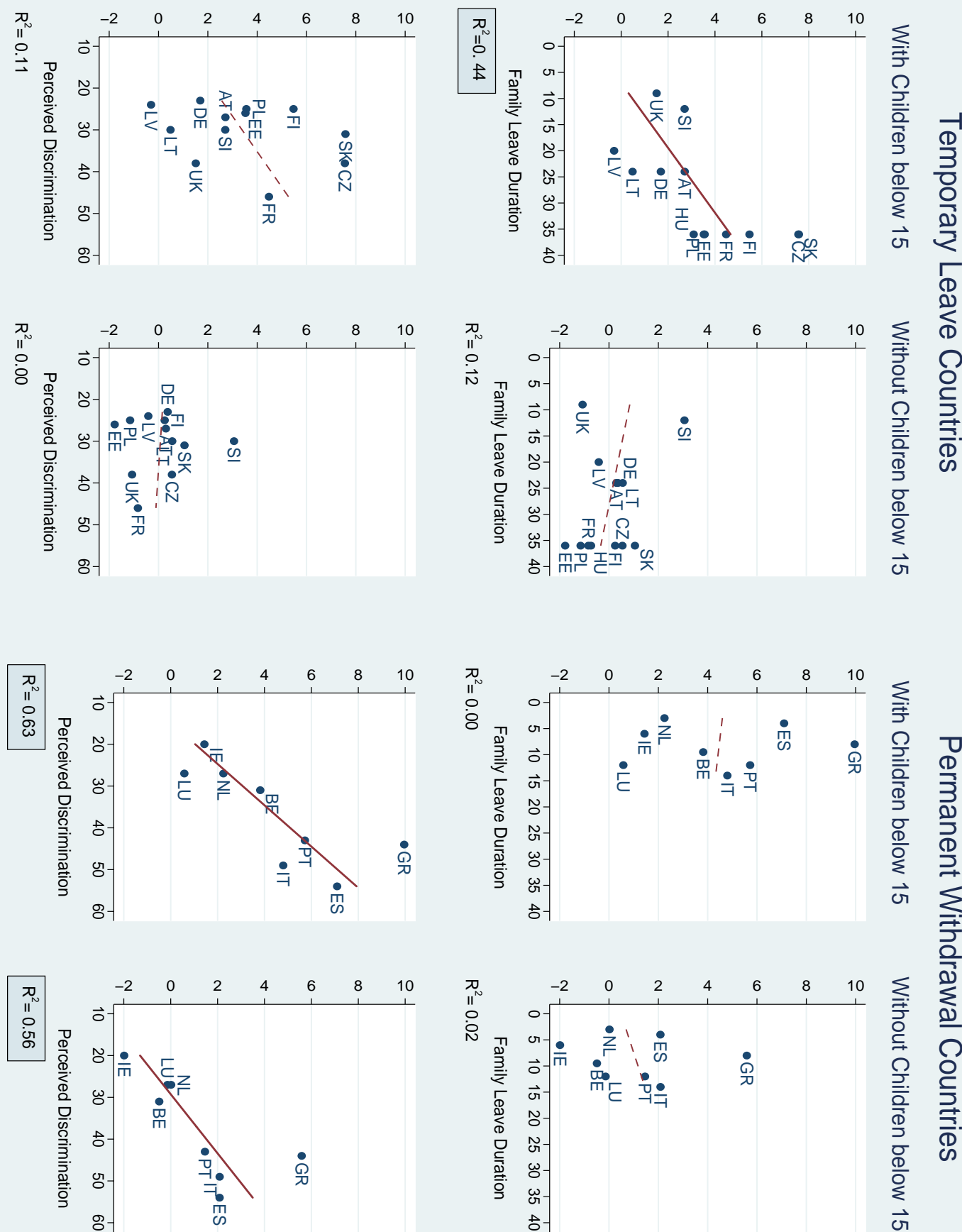

Note: EU LFS data. Own calculations. Five-year averages of gender unemployment gaps among prime age individuals over 2003-2007. Sampling weights are used for the construction of the annual gender unemployment gaps. Family leave duration is the maximum duration of total paid postnatal leave in months. Source: The Council of Europe Family Policy Database. Perceived gender discrimination is measured as the share of all respondents who perceive gender discrimination as widespread in their country. Source: Eurobarometer 2008. Straight lines show fit from an OLS regressions of gender unemployment gaps on a constant and the respective right-hand side variables. 
Figure A.3: Gender Unemployment Gaps 2000-2007

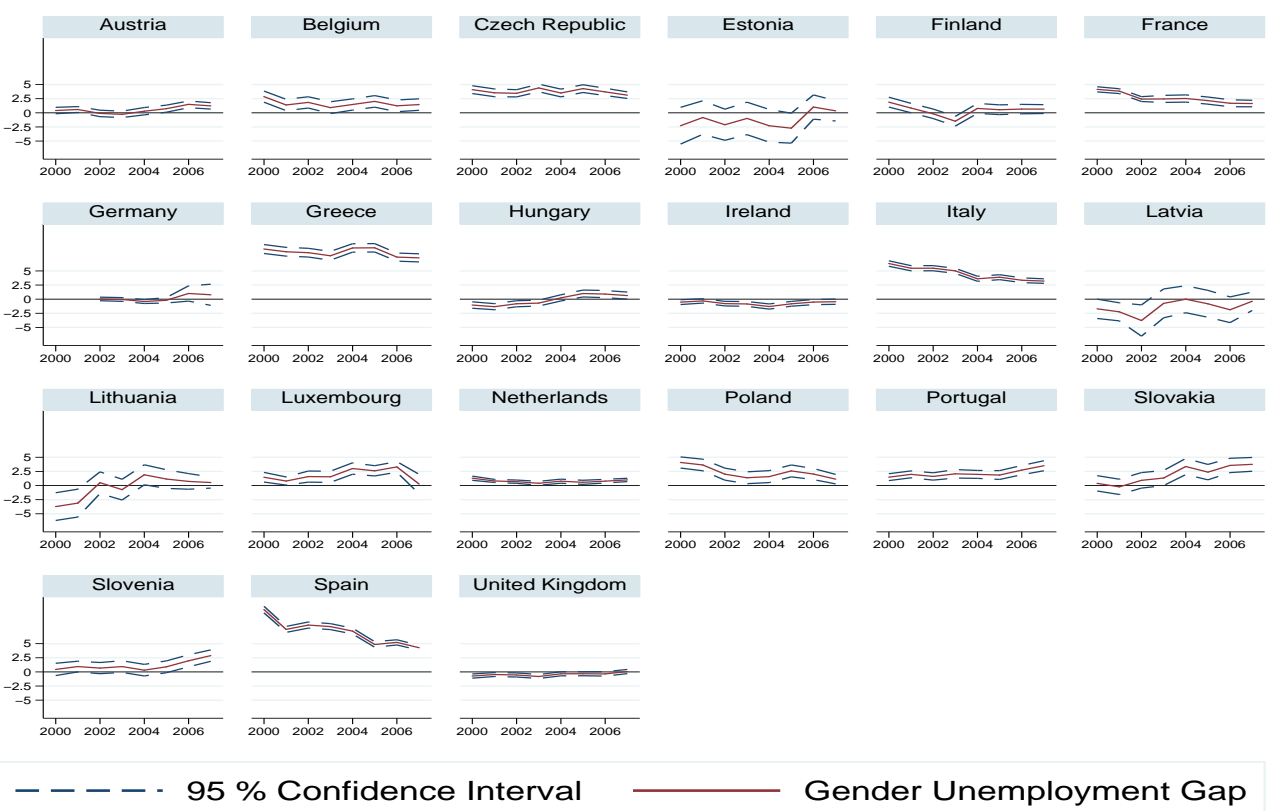

Note: EU LFS data, sample of individuals 25-54 years old. Sampling weights are used for the construction of the annual gender unemployment gaps. Gender unemployment gaps are measured in percentage points as the differences between female and male unemployment rates. $95 \%$ confidence intervals treat gender unemployment gaps as the difference between the means of binary variables from two independent samples.

Figure A.4: Labor Force Participation Rates by Gender 2000-2007
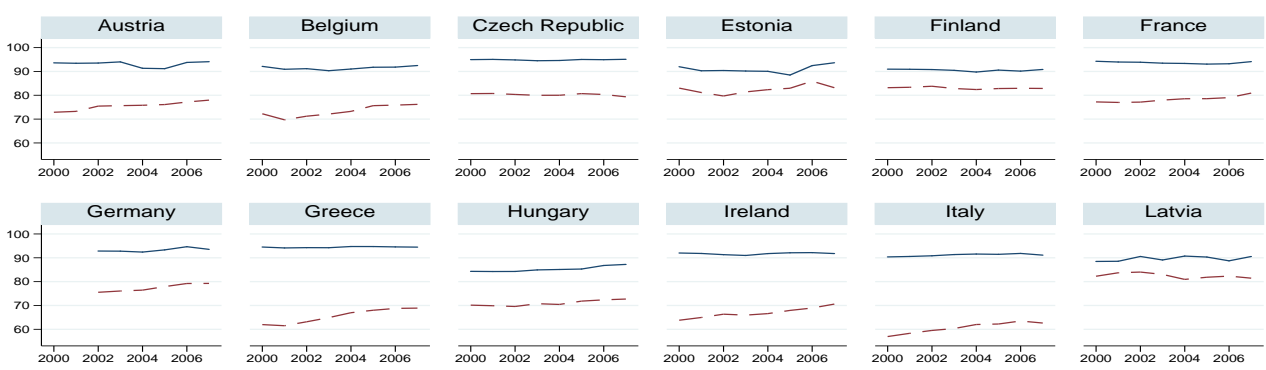

Ireland

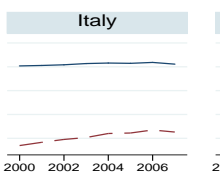

Latvia
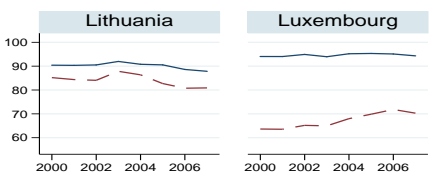

Netherlands
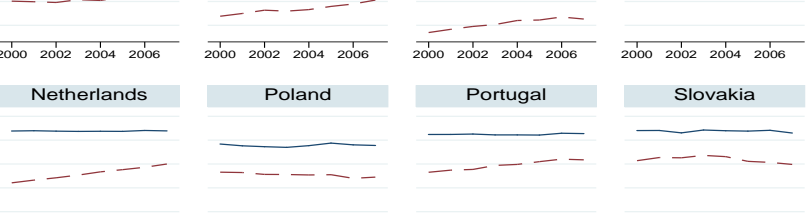

$\frac{1}{10002002} 20042006$

$\frac{1}{2000 \quad 2002 \quad 20042006}$

$\frac{1}{1} 20002002 \quad 10042006$

$\frac{1}{2000} 2002 \quad 20042006$
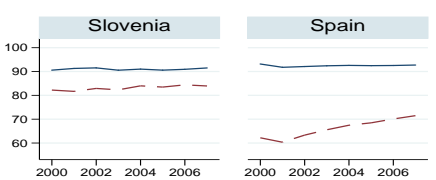

United Kingdom

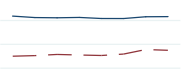

$\frac{1}{2000 \quad 200220042006}$

Men

\section{Women}

Note: EU LFS data, sample of individuals 25-54 years old. Sampling weights are used for the construction of the annual participation rates. The share of the sum of employed and unemployed in the population. 


\section{Working Paper Series}

ISSN 1211-3298

Registration No. (Ministry of Culture): E 19443

Individual researchers, as well as the on-line and printed versions of the CERGE-EI Working Papers (including their dissemination) were supported from institutional support RVO 67985998 from Economics Institute of the ASCR, v. v. i.

Specific research support and/or other grants the researchers/publications benefited from are acknowledged at the beginning of the Paper.

(c) Alena Bičáková, 2012

All rights reserved. No part of this publication may be reproduced, stored in a retrieval system or transmitted in any form or by any means, electronic, mechanical or photocopying, recording, or otherwise without the prior permission of the publisher.

Published by

Charles University in Prague, Center for Economic Research and Graduate Education (CERGE) and

Economics Institute ASCR, v. v. i. (EI)

CERGE-EI, Politických vězňů 7, 11121 Prague 1, tel.: +420 224005 153, Czech Republic.

Printed by CERGE-EI, Prague

Subscription: CERGE-EI homepage: http://www.cerge-ei.cz

Phone: + 420224005153

Email: office@cerge-ei.cz

Web: http://www.cerge-ei.cz

Editor: Michal Kejak

The paper is available online at http://www.cerge-ei.cz/publications/working_papers/.

ISBN 978-80-7343-279-9 (Univerzita Karlova. Centrum pro ekonomický výzkum a doktorské studium)

ISBN 978-80-7344-271-2 (Národohospodářský ústav AV ČR, v. v. i.) 
CERGE-EI

P.O.BOX 882

Politických vězňů 7

11121 Praha 1

Czech Republic http://www.cerge-ei.cz 